\title{
Tangled and drowned: a global review of penguin bycatch in fisheries
}

\author{
Rory Crawford $^{1, *}$, Ursula Ellenberg ${ }^{2,3,4}$, Esteban Frere ${ }^{1,5}$, Christina Hagen $^{6}$, \\ Karen Baird ${ }^{1,7}$, Paul Brewin ${ }^{8}$, Sarah Crofts ${ }^{9}$, James Glass ${ }^{10}$, Thomas Mattern $^{3,4}$, \\ Joost Pompert ${ }^{11}$, Katherine Ross ${ }^{9}$, Jessica Kemper ${ }^{12}$, Katrin Ludynia ${ }^{13,14}$, Richard B. \\ Sherley $^{15}$, Antje Steinfurth ${ }^{16}$, Cristián G. Suazo ${ }^{17,18}$, Pablo Yorio ${ }^{19,20}$, Leandro \\ Tamini $^{21}$, Jeffrey C. Mangel ${ }^{22,23}$, Leandro Bugoni ${ }^{24}$, Gustavo Jiménez Uzcátegui ${ }^{25}$, \\ Alejandro Simeone ${ }^{26}$, Guillermo Luna-Jorquera ${ }^{27}$, Patricia Gandini $^{5}$, \\ Eric J. Woehler ${ }^{28}$, Klemens Pütz ${ }^{29}$, Peter Dann ${ }^{30}$, Andre Chiaradia ${ }^{30}$, Cleo Small ${ }^{1}$ \\ ${ }^{1}$ BirdLife International Marine Programme, c/o RSPB, The Lodge, Potton Road, Sandy, Bedfordshire SG19 2DL, UK \\ Addresses for other authors are given in the Supplement at www.int-res.com/articles/suppl/n034p373_supp.pdf
}

\begin{abstract}
Penguins are the most threatened group of seabirds after albatrosses. Although penguins are regularly captured in fishing gear, the threat to penguins as a group has not yet been assessed. We reviewed both published and grey literature to identify the fishing gear types that penguins are most frequently recorded in, the most impacted species and, for these susceptible species, the relative importance of bycatch compared to other threats. While quantitative estimates of overall bycatch levels are difficult to obtain, this review highlights that, of the world's 18 species of penguins, 14 have been recorded as bycatch in fishing gear and that gillnets, and to a lesser extent trawls, are the gear types that pose the greatest threats to penguins. Bycatch is currently of greatest concern for yellow-eyed Megadyptes antipodes (Endangered), Humboldt Spheniscus humboldti (Vulnerable) and Magellanic Spheniscus magellanicus penguins (Near Threatened). Penguins face many threats; reducing bycatch mortality in fishing gear will greatly enhance the resilience of penguin populations to threats from habitat loss and climate change that are more difficult to address in the short term. Additional data are required to quantify the true extent of penguin bycatch, particularly for the most susceptible species. In the meantime, it is crucially important to manage the fisheries operating within known penguin foraging areas to reduce the risks to this already threatened group of seabirds.
\end{abstract}

KEY WORDS: Fishery $\cdot$ Gillnet $\cdot$ Seabird $\cdot$ Trawl $\cdot$ Conservation $\cdot$ Direct mortality

\section{INTRODUCTION}

Penguins are one of the most threatened groups of seabirds (Croxall et al. 2012), with 10 of the world's 18 species listed as Vulnerable or Endangered on the IUCN Red List and a further 3 deemed Near Threatened (BirdLife International 2017a). Numerous ter-

${ }^{*}$ Corresponding author: rory.crawford@rspb.org.uk restrial and marine threats contribute to this poor conservation status. On land, erosion, grazing and development resulting in habitat degradation, invasive alien species, human disturbance and disease are threatening several penguin species (García-Borboroglu \& Boersma 2013). At-sea threats include habitat degradation due to industrial and commercial 
development, as well as pollution and fisheries, both indirectly through overfishing of prey species and benthic habitat degradation from dredging or bottom trawls, and directly through bycatch in fishing gear (García-Borboroglu \& Boersma 2013). The potential impacts of climate change, both at sea and on land, are threatening breeding habitats and prey availability and are increasing the risk of disease (Trathan et al. 2015).

The bycatch of penguins in fishing gear has been the subject of few directed studies. Seabird bycatch more broadly has been widely studied and identified as a substantial threat to affected species (Croxall et al. 2012). The interactions between Procellariiformes and longline fisheries, where birds are accidentally captured on baited hooks (Brothers et al. 1999, Anderson et al. 2011), have been a focus of applied research. Furthermore, fatal interactions between large-winged seabirds (e.g. albatrosses) and trawl fisheries have been identified (Weimerskirch et al. 2000, Sullivan et al. 2006), due to the collision of birds with net warp cables when foraging for discards behind vessels (Sullivan et al. 2006, Watkins et al. 2008) and net entanglement when trawl nets are on the surface (Bull 2007, Pierre et al. 2013). More recently, bycatch in purse seine fisheries has been observed in Portugal (Oliveira et al. 2015) and Chile (Suazo et al. 2016), principally affecting shearwaters. Incidental capture in gillnet fisheries is estimated to kill at least 400000 seabirds annually, with pursuit-diving seabirds identified as particularly vulnerable (Žydelis et al. 2013).

Penguins, as pursuit divers, are most likely to interact with gillnets (Žydelis et al. 2013) and trawls (Gandini et al. 1999, González-Zevallos \& Yorio 2006), although they have also been recorded as bycatch in longline fisheries in low numbers (Nel et al. 2002, CCAMLR 2011). Penguin interactions with gillnets are poorly understood, but entanglements are suspected to occur when birds are actively foraging (Simeone et al. 1999, Pütz et al. 2011), transiting or resting on the surface (Majluf et al. 2002). Penguin interactions with trawl fisheries have been primarily recorded in Argentina, where Magellanic penguins Spheniscus magellanicus are captured during the haul as they attempt to feed on small non-target fish that drop out of the net (González-Zevallos \& Yorio 2006).

The limited published literature on penguin bycatch is partially explained by the small-scale nature of the fisheries with which penguins are most likely to interact, particularly gillnet fisheries (Žydelis et al. 2013). In general, such fisheries are highly dispersed and diverse among jurisdictions, making monitoring and enforcement difficult. For example, Peru, Chile and Ecuador are together estimated to host around 90000 artisanal fishing vessels, with boats fishing from numerous locations along the Pacific coast of South America (Goya et al. 2011).

In spite of the threatened status of many penguin species (BirdLife International 2017a) and the clear impact of bycatch on other seabirds (Anderson et al. 2011, Croxall et al. 2012), there has been no attempt so far to collate the available data to understand the potential impacts, knowledge gaps and conservation priorities. Here, we aim to address this by reviewing the published and grey literature to identify: (1) the fishing gears of greatest concern with regard to penguin bycatch; (2) the species most at risk from bycatch (and for these species, the relative importance of bycatch compared to other threats); (3) the areas of considerable penguin-fisheries interaction; (4) key conservation actions.

\section{METHODS}

A workshop on penguin bycatch at the $8^{\text {th }}$ International Penguin Conference in Bristol in 2013 brought together a network of experts that committed to collating all available knowledge on the topic. The results of the extensive literature review on global penguin bycatch were then discussed at a follow-up bycatch workshop during the $9^{\text {th }}$ International Penguin Conference in Cape Town in 2016. The collated information includes published and unpublished scientific papers and reports identified via searches in Internet repositories (e.g. Google Scholar), Web of Science and authors' own (or associated) unpublished works. The limited number of publications on penguin bycatch (Figs. 1 \& 2) means that some older, potentially outdated, papers are referenced; thus some fisheries activities may have changed in the intervening period. However, all information presented here was included for its broader relevance in understanding the scale and species involved in penguin bycatch. Where bycatch rates are available, these data and associated fleetwide bycatch estimates are included, although many incidents are recorded simply as the number of birds caught on a single trip.

This review is undoubtedly impacted by publishing bias, and anecdotal reports of large bycatch events are also more likely to be recorded than zero catches (Wallace et al. 2010). In addition, studies are often not conducted randomly, and may have been focussed in 


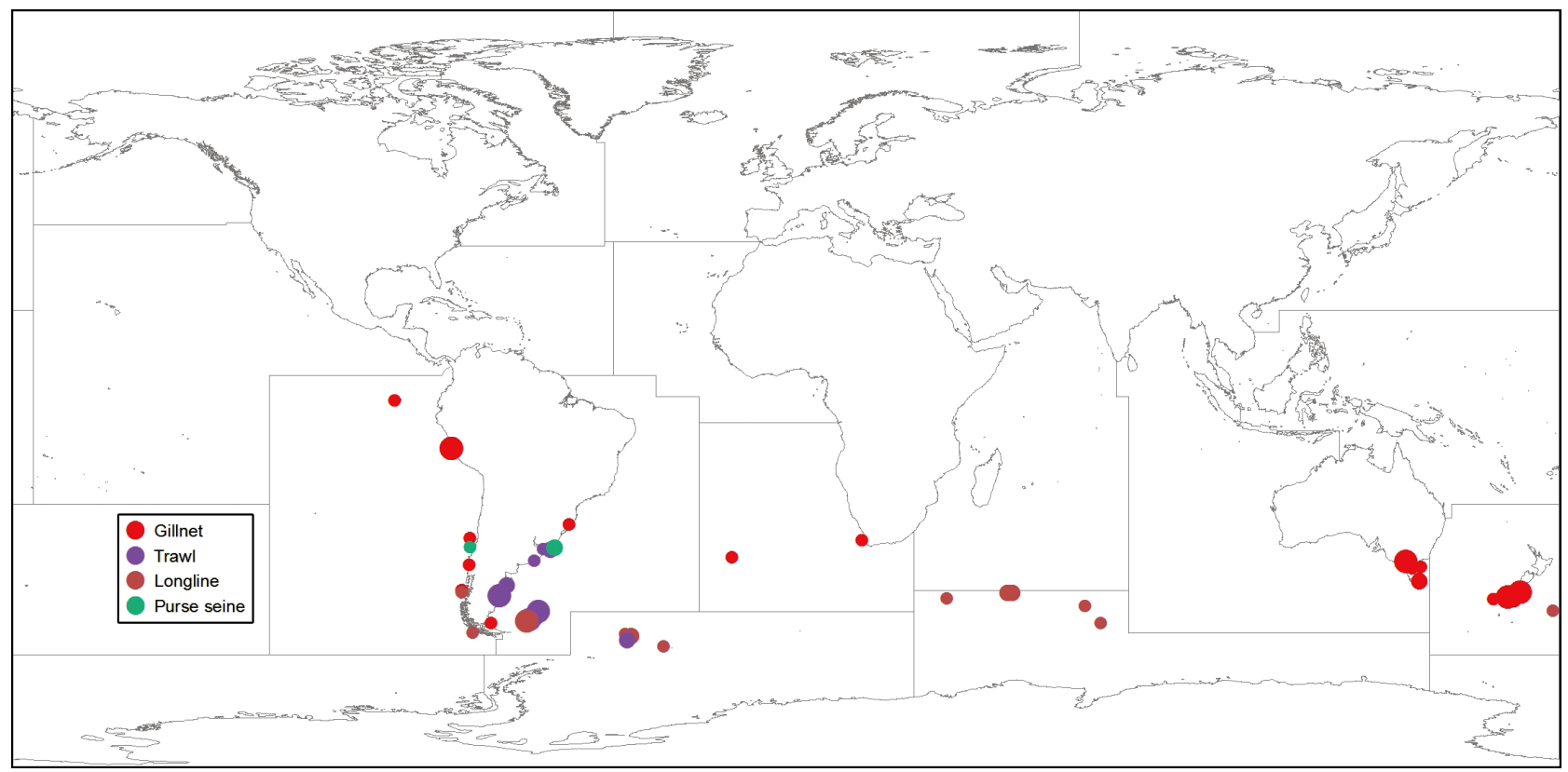

Fig. 1. Penguin bycatch records in gillnets, trawls, longlines and purse seine fisheries. Records were assigned to the area from which the data were obtained (where available; data without a specific location were assigned within the relevant species' range) (coloured circles). The size of the circles indicates the relative number of records for that location. Source: Royal Society for the Protection of Birds

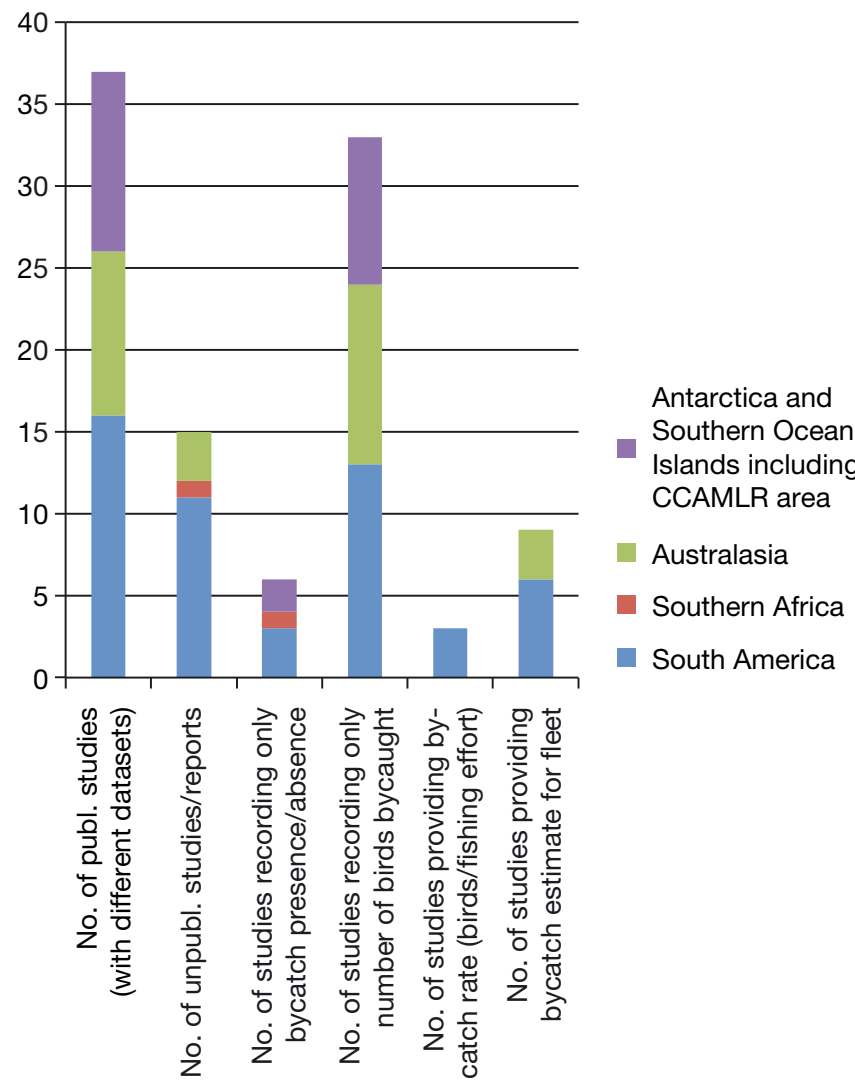

Fig. 2. Summary of penguin bycatch records used in this review (by region). Data are from published and unpublished studies unless otherwise stated areas of perceived conflict or where resources happen to be available (Figs. 1 \& 2). Irrespective, this review will use the available information to broadly identify the species, regions and gears of concern to focus further efforts. Species' ecology, fisheries active in their range and consideration of the relative importance of bycatch versus other threats are all factors used to determine future priorities.

Results are grouped into 4 regions: South America, southern Africa, Australasia, and Antarctica including the Southern Ocean islands. They are further divided into countries where relevant. For each country, data are presented for the different fishing methods used. This approach allows cumulative impacts for species across national jurisdictions to be considered based on all fishing methods in use, but also results in the identification of relevant national-level recommendations.

Penguin populations in the Antarctic and Southern Ocean islands were considered as a separate region because of their low coastal fisheries effort, as well as similar management regimes, particularly under the Convention for the Conservation of Antarctic Marine Living Resources (CCAMLR). The issues, species and management structures were considered to be more relatable on this basis, rather than attempting to link islands to distant continental land masses. 


\section{RESULTS}

\section{South America}

Breeding colonies of 7 species of penguins are found in 4 countries (plus the Falkland Islands/Islas Malvinas) in South America: Magellanic Spheniscus magellanicus and southern rockhopper Eudyptes chrysocome (both breed in Argentina, Chile and the Falkland Islands/Islas Malvinas ${ }^{1}$ ), Humboldt $S$. humboldti (Chile, Peru), Galápagos S. mendiculus (Ecuador), macaroni E. chrysolophus and king Aptenodytes patagonicus (both found in the Falkland Islands/Islas Malvinas and Chile) and gentoo Pygoscelis papua (Argentina and the Falkland Islands/Islas Malvinas) (Kusch \& Marin 2012, García-Borboroglu \& Boersma 2013). During the non-breeding period (austral autumn and winter), Magellanic penguins from colonies at the Atlantic/Argentinean coast migrate through and feed in the waters off Uruguay and Brazil.

Trawls and gillnets are the most important fishing gears that penguins interact with in South America (Table 1) (Simeone et al. 1999, González-Zevallos \& Yorio 2006, Žydelis et al. 2013). Due to the spatial extent of these fisheries and differences in gear specifications and fishing operations, the interaction between fisheries and penguins - and the available information on these interactions - varies significantly amongst the countries in South America.

\section{Argentina}

Trawl fisheries. Penguin bycatch in Argentina has largely been recorded in trawl fisheries, particularly focussed on Golfo San Jorge, Patagonia, which is home to over $15 \%$ of the total Argentinean breeding population of Magellanic penguins (Pozzi et al. 2015), estimated at 950000 birds (Schiavini et al. 2005).

The Argentine red shrimp Pleoticus muelleri doublerig beam freezer trawl fishery active in Golfo San Jorge was estimated, based on direct observation on vessels, to kill $642( \pm 225)$ Magellanic penguins annually in the late 1990s (Gandini et al. 1999). Further observations, conducted between 2005 and 2007, estimated 895 penguin mortalities fleet-wide across the 3 years of the study period (González-Zevallos et

\footnotetext{
${ }^{1}$ A dispute exists between the Governments of Argentina and the UK concerning sovereignty over the Falkland Islands (Islas Malvinas), South Georgia and the South Sandwich Islands (Islas Georgias del Sur y Islas Sandwich del Sur) and the surrounding maritime areas.
}

al. 2011). This study also highlighted that Magellanic penguin bycatch was more likely closer to shore, and that mortality increased with longer hauls (GonzálezZevallos et al. 2011).

High seas ice trawlers target Argentine hake Merluccius hubbsi in the same fishing area from September to May. Direct observation has given variable estimates of fleet-wide Magellanic penguin mortality over 2 yr: 35 deaths were estimated in 2003, and 1516 in 2004 (González-Zevallos \& Yorio 2006). Although there are no recent studies of this fishery, foraging Magellanic penguins continue to overlap with shrimp and hake vessels operating in adjacent waters during the breeding season (Yorio et al. 2010).

Marinao \& Yorio (2011) studied the incidental mortality of seabirds in the coastal ice trawlers targeting Argentine red shrimp in the Isla Escondida fishing area, estimating 53 Magellanic penguins killed in 3149 hauls from 2006-2008, a mortality rate of 0.003 penguins haul ${ }^{-1}$. Penguin bycatch was also recorded from 2008-2012 in both the coastal red shrimp and hake fishery operating in the same area (Marinao et al. 2014). In total, 203 adult Magellanic penguins were incidentally caught in nets, occurring almost exclusively in the hake fishery $(97.5 \%$ of captures) and largely occurring closer to penguin colonies (85\% of captures within $45 \mathrm{~km}$ of the coast; Marinao et al. 2014). Mean monthly capture rate was 0.087 birds haul $^{-1}$ (range 0.01-2.07 birds haul ${ }^{-1}$ ).

Lower levels of Magellanic penguin bycatch have been recorded in the cornalito Odontesthes incisa pelagic pair trawl fishery in Puerto Quequén $\left(38^{\circ} \mathrm{S}\right.$, $58^{\circ} \mathrm{W}$ ), with an annual estimated mortality of 100 penguins (Tamini et al. 2002), and in the mid-water coastal fishery targeting silversides Odontesthes spp. along the northern coast of Argentina (3 captures across 28 d; Seco Pon et al. 2013).

Small-scale fisheries (gillnets). Very few data are available from small-scale fisheries, including coastal gillnets, from areas that overlap with Magellanic penguins at sea. This is an important knowledge gap given the high risk to penguins from gillnets. Bycatch has been recorded in the south of Argentina: from 1995-1999, around 1000 penguins were estimated to have been killed annually (Schiavini et al. 2005, P. Gandini \& E. Frere unpubl. data).

\section{Falkland Islands (Islas Malvinas)}

Trawl fisheries. The Doryteuthis gahi squid fishery in the Falkland Islands comprises 16 bottom trawlers operating to the east and southeast of the islands, 


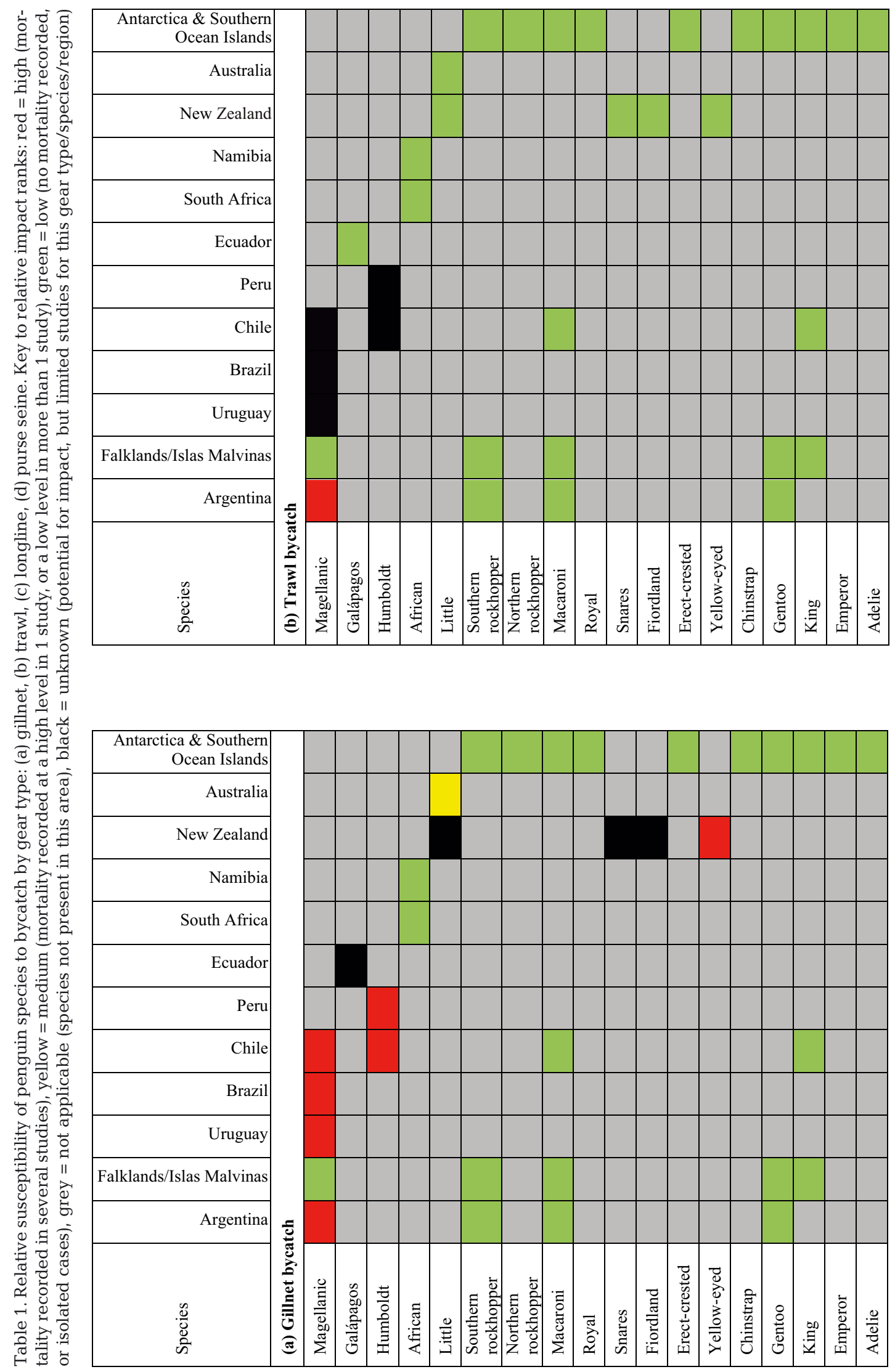




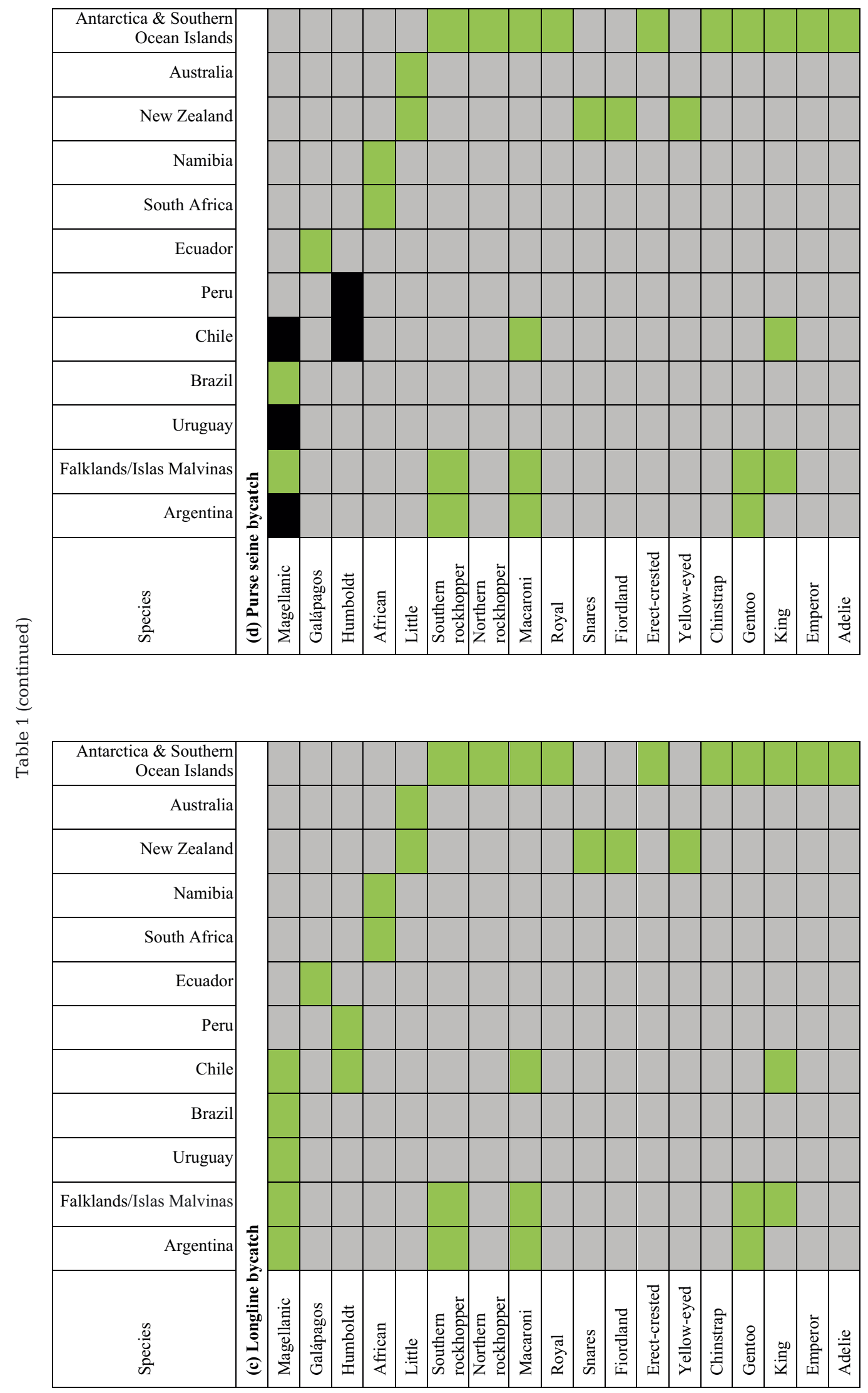


largely within $65 \mathrm{~km}$ of the coast. Between 1995 and 2001, low levels of net-related bycatch were recorded for several penguin species, including 1 king penguin, 6 gentoo penguins and 7 Magellanic penguins, most of which occurred off Volunteer Point $\left(51^{\circ} \mathrm{S}\right.$, $57^{\circ} \mathrm{W}$ ) in an area now closed to fishing (Falkland Islands Fisheries Department unpubl. data).

The mixed finfish and skate fleet mainly fishes in deeper water $(>140 \mathrm{~m})$, so while this fishery does cause some seabird mortalities (primarily blackbrowed albatrosses Thalassarche melanophris), penguin fatalities are believed to be very rare: a single king penguin mortality was recorded in 2009 (Falkland Islands Fisheries Department unpubl. data).

In October 2012, a research trip on a commercial bottom trawler caught 23 gentoo penguins over $3 \mathrm{~d}$ to the north-east of the islands: 6 of these birds drowned, and 17 survived and were released (Roux et al. 2012). Dissection revealed that several penguins had been feeding on fishery discards. Since 1988, observers have been placed regularly on comparable vessels fishing in the same area, and penguin captures have not been reported (J. Pompert pers. obs.).

Jigging fisheries. Squid jigging (targeting Illex argentinus) accounts for the largest component of catches in the Falkland Islands, with vessels operating between the Falkland Islands and Argentina. Barton (2002) reported that low numbers of penguins are occasionally hooked by the small barbless hooks on the jigging lures and brought on board. After a period on the vessel they are released apparently unharmed. Observers present on the ship inspect animals for cuts, but have generally reported injury to be of a very minor nature (J. Pompert pers. obs.).

Longline fisheries. The single Patagonian toothfish Dissostichus eleginoides demersal longline vessel fishing in Falkland Islands waters is Marine Stewardship Council certified and has not recorded any penguin bycatch (with high levels of observer coverage: $40-80 \%$ of effort was observed between 2002 and 2012; Andrews et al. 2014). In September 2006, an experimental longline fishery for kingclip Genypterus blacodes hooked and drowned 5 gentoo penguins (Falkland Islands Fisheries Department unpubl. data).

Despite 2 significant bycatch events, overall penguin bycatch is believed to be rare in Falkland Islands fisheries. Gentoo penguins appear to be the most susceptible species, although Magellanic and southern rockhopper penguins that breed in the Falklands may be vulnerable on their wintering grounds in Argentinean, Uruguayan and Brazilian waters.

\section{Uruguay}

Minimal penguin bycatch data are available for Uruguay, though there is some information in the National Plan of Action-Seabirds (Domingo et al. 2015).

Trawl fisheries. The demersal trawl fishery for Argentine hake has recorded Magellanic penguins entangled in nets, but there is no quantitative estimate of the numbers of penguins involved. The coastal trawl fishery targeting whitemouth croaker (locally known as corvina) Micropogonias furnieri and weakfish Cynoscion guatucupa uses 2 vessels trawling a single net, and incidental captures of Magellanic penguins have been reported (Karumbé unpubl. data).

Gillnet fisheries. Both artisanal and industrial gillnet fisheries operate in Uruguay, using bottom and surface-set nets, though primarily the former. The main target species are whitemouth croaker and weakfish, and seabird bycatch has been detected, but has not been recorded to species level. In line with reports from Brazil, it seems likely that it is Magellanic penguins that are captured in these fisheries.

Purse seine fisheries. National observers have recorded Magellanic penguin bycatch in the Uruguayan purse seine fishery targeting anchoita Engraulis anchoita, but no quantitative data are available.

\section{Brazil}

Gillnet fisheries. Gillnets are the only fishing gear in which substantial penguin bycatch has been recorded in Brazil, and those operating in the south, overlapping with Magellanic penguins, can be broadly placed in 3 categories: the surface or driftnet fishery targeting bluefish Pomatomus saltatrix; bottom-set gillnets targeting weakfish and Argentine croaker Umbrina canosai; and bottom-set gillnets targeting whitemouth croaker. Penguin bycatch has been recorded in all of these fisheries, but vessels targeting bluefish are of greatest concern (L. Bugoni unpubl. data).

Cardoso et al. (2011) undertook observations on a gillnet vessel typical of the Passo de Torres fleet in southern Brazil, which deployed both driftnets for bluefish and bottom-set gillnets for weakfish and Brazilian codling Urophicys brasiliensis. From 17 observed sets over 8 d, 68 Magellanic penguins (predominantly adults) were killed: 56 in driftnets (mean \pm SD: $2.65 \pm 1.47$ birds km$~_{-1}$ of net $\mathrm{d}^{-1}$ ), and 12 in bottom-set gillnets $\left(0.22 \pm 0.16\right.$ birds km$~^{-1}$ of net $\left.\mathrm{d}^{-1}\right)$. 
Based on interviews with fishermen, Vasconcellos et al. (2014) reported that incidental capture of penguins is more common in both drift and bottom-set gillnets near the Uruguayan border. This is consistent with the distribution of larger schools of anchoita, the main Magellanic penguin prey north of $47^{\circ} \mathrm{S}$ (Frere et al. 1996). In 2008, 280 gillnet vessels were fishing with driftnets and/or bottom-set gillnets from ports in southern Brazil (IBAMA/CEPERG 2009, UNIVALI 2009). A recent estimate suggested that over 350 vessels operated in Santa Catarina and Rio Grande do Sul states (Vasconcellos et al. 2014), so the scale of bycatch over this entire fleet could be substantial.

\section{Chile}

Gillnet fisheries. Based on observation of fishing activities, beached bird surveys and interviews with fishermen, 605 Humboldt and 58 Magellanic penguins were reported drowned as bycatch between 1991 and 1996 in the corvina Cilus gilberti gillnet fishery operating in central Chile $\left(\sim 33^{\circ} \mathrm{S}\right.$; Simeone et al. 1999).

Mass penguin mortality events of several hundred birds in south-central Chile $\left(39^{\circ} \mathrm{S}\right)$ have also been linked to bycatch. Schlatter et al. (2009) reported 1380 stranded Magellanic penguins (adults and juveniles) at Queule. Based on injuries consistent with entanglement and on interviews with local fishermen, these authors attributed this mortality event to drowning in artisanal gillnets targeting southern rays bream Brama australis and corvina. Skewgar et al. (2009), Pütz et al. (2011) and Suazo et al. (2013) also reported a low number of records of entangled Magellanic penguins in local gillnet fisheries close to Chiloé Island $\left(42^{\circ} \mathrm{S}, 74^{\circ} \mathrm{W}\right)$ and Chonos Archipelago $\left(45^{\circ} \mathrm{S}, 73^{\circ} \mathrm{W}\right)$ in southern Chile.

Purse seine fisheries. Recent observations in both artisanal and industrial purse seine vessels targeting sardine Strangomera bentincki show that penguins can be captured in this gear: a total of 4 Magellanic penguins were recorded in 16 monitored trips in 2014 (Albatross Task Force-Chile unpubl. data), which merits further investigation.

Longline fisheries. There are scattered records of penguin bycatch from the sub-Antarctic fjords in southern Chile. Among these are 3 southern rockhopper penguins from 17 monitored trips (J. Ojeda pers. comm.), which were hooked in small-scale vertical drifting longlines set for southern hake Merluccius australis (see Moreno et al. 2006, Suazo et al. 2013).
Overall, it is thought that small-scale fisheries, particularly gillnets and purse seines, are the main fisheries threatening penguins in Chile (Suazo et al. 2014)

Peru

Evidence of incidental catch and mortality of penguins in Peruvian gillnet fisheries has been noted since the early 1980s (Duffy et al. 1984, Hays 1984, Araya 1988).

Gillnet fisheries. Incidental capture in gillnets has previously been reported as the main cause of mortality for the Punta San Juan $\left(12^{\circ} \mathrm{S}, 77^{\circ} \mathrm{W}\right)$ and nearby colonies, with about 400 Humboldt penguins reported dead in 1992 (Zavalaga \& Paredes 1997). Observers stationed at San Juan port recorded landings of 922 dead Humboldt penguins between 1991 and 1998 (Majluf et al. 2002). The majority of these were captured in the surface driftnet fleet targeting cojinova Seriolella violacea, with lower bycatch rates in fixed demersal gillnets (Majluf et al. 2002). This study also highlighted that driftnets were usually set through the night, and penguins were thought to have been captured when staying at sea overnight, resting on the surface (Majluf et al. 2002). It is suspected that mortality could be exacerbated by retention of incidentally captured penguins for human consumption, as active targeting of penguins with gillnets has been recorded (P. McGill pers. comm.).

Humboldt penguin bycatch has also been recorded in the demersal set net fishery for guitarfish Rhinobatos planiceps in Constante $\left(5^{\circ} \mathrm{S}, 99^{\circ} \mathrm{W}\right)$ and in the driftnet fishery for sharks and rays in Salaverry $\left(8^{\circ} \mathrm{S}\right.$, $79^{\circ} \mathrm{W}$; Alfaro-Shigueto et al. 2010). Between 2000 and 2015, this observer programme recorded bycatch of 22 penguins from 6 fishing ports, the majority of which were captured in surface driftnets set at night (Pro Delphinus unpubl. data).

Artisanal vessels, many of which use gillnets, are the main threat to penguins. Considering that there are more than 10000 such vessels in the country (Goya et al. 2011), the impact of this large fleet may be significant for Humboldt penguins.

\section{Ecuador}

The Galápagos penguin S. mendiculus is an Endangered species endemic to the Galápagos Islands, with an estimated population of 1200 individuals (BirdLife International 2017a), and is the only pen- 
guin species breeding in Ecuador (Harris 1973). With the creation of the Galápagos Marine Reserve (GMR), industrial fishing was banned and fishing rights were granted exclusively to the local small-scale, or artisanal, fishing sector (MAE-DPNG 2006, Asamblea Nacional 2015).

Despite being illegal in the GMR, gillnets are regularly used in shallow areas to target schooling fish. Penguin bycatch has been recorded in these nets in the waters off Villamil, Isabela Island, but quantitative figures are not available (A. Steinfurth pers. obs., Galápagos National Park Directorate unpubl. data). A small number of birds have also been found entangled in discarded 'ghost' fishing gear in the Bolivar Channel (potentially originating outside the GMR; Galápagos National Park Directorate pers. obs.).

With few records of fisheries-related penguin mortality in Ecuador, and no legal gillnet fishery, penguin bycatch does not appear to be a major threat. However, it is suspected that bycatch is under-reported, particularly because it occurs in illegal fisheries. There is a clear need for contemporary data to ascertain the threat illegal fishing poses to the endangered Galápagos penguin.

\section{Southern Africa}

The African penguin $S$. demersus is endemic to southern Africa and is the only breeding penguin on the African continent (Crawford et al. 2011). Although vagrant birds have been found as far north as Gabon on the African west coast and Mozambique on the east coast, this species breeds only from central Namibia to Bird Island, Algoa Bay, in South Africa's Eastern Cape (Crawford et al. 2013). Some birds, particularly non-breeding birds (Shelton et al. 1984) and juveniles (Sherley et al. 2017) do venture north into Angolan waters.

The species is currently listed as Endangered (BirdLife International 2017a) due to a large population decrease over the preceding $30 \mathrm{yr}$ (Crawford et al. 2011). The main cause of the decrease is thought to be related to prey (sardine Sardinops sagax and anchovy Engraulis encrasicolus) availability (Crawford et al. 2011). Mortality of African penguins in fishing gear is unquantified in the region (Figs. $1 \& 2$ ).

\section{South Africa}

Purse seine fisheries. South Africa's purse seine fishery targets mainly sardine, anchovy and red eye round herring Etrumeus whiteheadi and is the country's largest commercial fishery by landed mass (Prochazka 2014). It is thought that African penguins avoid fishing vessels, although there are conflicting accounts $(\mathrm{H}$. Terblanche and S. Hampton pers. comm.). There have been no reports of African penguin captures in these nets (L. Pichegru pers. comm.), but there are no independent observers in this fishery to verify this.

Gillnet fisheries. Beach seine and gillnet fisheries are active throughout South Africa (Prochazka 2014), with the largest targeting harder (mullet) Liza richardsonii. These fisheries are effort managed, but there are substantial numbers of illegal fishers (Prochazka 2014). Much of the effort is focussed around river mouths, estuaries and on the west coast, where the fisheries overlap with the distribution of penguin breeding colonies.

Several hundred African penguins were reportedly caught in gillnets around Dassen and Robben Islands until gillnet exclusion zones were put in place in 2001. Any bycatch that now occurs in these areas would be from illegal or ghost gillnets. St. Joseph shark Callorhinchus capensis gillnets, and those targeting smooth-hound sharks Mustelus mustelus and various species of 'linefish' (those generally caught on lines from shore or small vessels), are likely to be responsible for penguin bycatch, if any occurs. Bycatch from illegal fishing is exceedingly difficult to quantify (all information from S. Lamberth pers. comm.).

Trawl fisheries. Three main trawl fisheries operate in South Africa: the demersal trawl fishery targeting shallow-water cape hake Merluccius capensis and deep-water cape hake $M$. paradoxus, the inshore trawl fishery targeting a mix of species including Agulhas sole Austroglossus pectoralis and the cape hakes, and the midwater trawl fishery targeting cape horse mackerel Trachurus capensis. The demersal trawl fishery is unlikely to be a source of bycatch mortality as it has minimal overlap with foraging African penguins, and the species is not known to take discards. Fisheries observers on trawl vessels (approximately $20 \%$ observer coverage) have never recorded penguin mortality in this fishery (B. Maree pers. comm.).

No instances of penguin mortality have been recorded in the inshore trawl fishery. African penguins do not forage on the species targeted by the fishing vessels and are therefore unlikely to be in the same area at the time of fishing.

Longline fisheries. Limited longline fishing for tuna and billfish occurs in South African and Namibian 
waters. Lines are generally set offshore (B. Lebepe pers. comm.), beyond the average foraging range of the African penguin, which is around $20 \mathrm{~km}$ from the coast (Wilson et al. 1988, Ludynia et al. 2012).

\section{Namibia}

Namibia has purse seine and longline fisheries similar to South Africa, and the issues around penguin bycatch (or lack thereof) are currently believed to be similar and are not discussed further. However, while no penguin mortalities have been recorded, it should be emphasised that there is limited observer coverage.

Gillnet fisheries. The use of gillnets is prohibited in Namibia, but the small-scale artisanal/recreational use of set nets is tolerated by fisheries inspectors in a bay close to the African penguin colony on Halifax Island. Small pieces of broken gillnet are regularly found washed up on beaches in the area (J. Kemper pers. obs.). Although this is a very localized and smallscale fishery (perhaps fewer than 8 rowing boats), the close proximity of gillnet fishing activities (and the projected path of 'ghost' net fragments drifting with the prevailing current) to Halifax Island $\left(26^{\circ} \mathrm{S}, 15^{\circ} \mathrm{E}\right)$ and the overlap with penguin foraging paths constitute a potential threat. Gillnet entanglement has been directly observed for crowned cormorants Microcarbo coronatus, and fragments of gillnets have been recovered from crowned and cape cormorant Phalacrocorax capensis nests (J. Kemper pers. obs.).

Trawl fisheries. Horse mackerel catches in the midwater trawl industry have dominated Namibian landings for the last $30 \mathrm{yr}$ (Roux et al. 2013). While no African penguin bycatch has been reported (J. Kemper pers. obs.), this is an important knowledge gap to fill due to the scale of the fishery.

\section{Australasia}

Nine penguin species are found in Australia, New Zealand and their sub-Antarctic territories. This section excludes the islands Macquarie, Heard, McDonald (to Australia) and Antipodes, Auckland and Campbell (to New Zealand), which are considered below in the 'Southern Ocean Islands' section.

The focus for this region is on 3 of the 4 New Zealand endemics: the Endangered yellow-eyed Megadyptes antipodes, the Vulnerable Snares Eudyptes robustus and Fiordland E. pachyrhynchus penguins, and the little penguin Eudyptula minor
(BirdLife International 2017a). Little penguins are the only mainland species in Australia; they are also found on the New Zealand mainland. Recent research suggests that Australian and New Zealand little penguins are separate species (Grosser et al. 2015). This may have implications for conservation status and actions, but since the little penguin is formally recognised as a single species at the time of writing (BirdLife International 2017b), we consider it here as a single species.

Yellow-eyed penguins also have populations on the sub-Antarctic Auckland and Campbell Islands (Seddon et al. 2013), but these birds are genetically isolated from the mainland population (Boessenkool et al. 2009) and should be considered separately for management purposes (Ellenberg \& Mattern 2012).

Both the Australian and New Zealand commercial fishing fleets include larger industrial vessels operating offshore, primarily utilising trawls and longlines, in addition to smaller inshore operations that use a variety of gear types. Of these, gillnets are believed to be of greatest concern for penguins, although independent observer data are sparse (Table 1).

\section{New Zealand}

Gillnet fisheries. Gillnets, also called set nets in New Zealand, are the primary gear type of concern with regard to penguin bycatch. The recreational sector focusses effort inshore, whereas the commercial sector fishes more extensively on the continental shelf around the New Zealand mainland (Ministry of Primary Industries 2015). The number of gillnet vessels has decreased in recent years; at present, around 330 commercial vessels use this gear in New Zealand waters (Ministry of Primary Industries 2012a), with operations primarily targeting demersal fish species (such as tarakihi Nemadactylus macropterus, jock stewart Helicolenus percoides, rig Mustelus lenticulatus and school shark Galeorhinus galeus). These fisheries overlap spatially with the benthic foraging yellow-eyed penguin.

In 2008, an inshore gillnet ban of between 2 and 4 nautical miles offshore was introduced around the South Island to reduce Hector's dolphin Cephalorhynchus hectori bycatch. This ban may have contributed to a reduction in the impact of recreational gillnets on penguins, though is unlikely to have substantially reduced the risk from commercial gillnets, as key yellow-eyed penguin foraging grounds have been identified $15-20 \mathrm{~km}$ from the shore (Mattern et al. 2007, Ellenberg \& Mattern 2012). 
Darby \& Dawson (2000) reported a total of 72 entanglements of yellow-eyed penguins (62\% of which were adults), corresponding to $\sim 12$ mortalities $\mathrm{yr}^{-1}$, primarily around the Otago Peninsula and north Otago $\left(45^{\circ} \mathrm{S}, 171^{\circ} \mathrm{E}\right)$ between 1979 and 1997 . Bycatch in commercial gillnets occurred predominantly in bottom set nets at depths $>70 \mathrm{~m}$, more than $15 \mathrm{~km}$ offshore.

Hocken (2005) analysed the cause of death in 114 yellow-eyed penguins collected opportunistically from 1996-2003 and found that at least 6 had been trapped in nets, diagnosed by characteristic bruising about the neck and shoulders. Anecdotal evidence suggests that bycatch continues to occur, and that previously reported numbers may represent an underestimate (Ellenberg \& Mattern 2012).

More recent observer coverage of commercial gillnetters reported 9 captures of yellow-eyed penguins over a 5 yr period (2005-2010; Rowe 2008, 2009, 2010, Ramm 2010, 2012a,b), much lower than Darby \& Dawson (2000), which itself was considered to be an underestimate of actual bycatch. The low number of yellow-eyed penguin deaths reported through the observer programme in recent years may be related to overall low levels of observer coverage (1.5\% of effort), and a lack of monitoring on gillnetters operating in important yellow-eyed penguin foraging areas (Richard \& Abraham 2013). Based on the limited observer dataset, Richard \& Abraham (2015) estimated fatalities of mainland population yellow-eyed penguins in gillnets to be on average 35 birds $\mathrm{yr}^{-1}$ (range: 16-60 birds), with the largest proportion (ca. $70 \%$ ) taken in demersal nets set for sharks. Population viability analysis shows that this level of mortality could have population-level effects (McKinlay 1997). In 2016, another 4 yellow-eyed penguins were recorded as bycatch in commercial gillnetters targeting school shark (observer coverage $2.8 \%$ effort; Ministry of Primary Industries 2017). Two of these birds were caught off the Waitaki River Mouth, 1 off Kaka Point and another off Stewart Island. Given the species' precarious situation, with low numbers (216 breeding pairs on the New Zealand South Island in 2015-16) and an overall decreasing population at previous strongholds (76\% decline between 1996 and 2016; Ellenberg \& Mattern 2012, Mattern et al. 2017), the effects of gillnet bycatch on the species may be significant and merits closer examination.

Little information is available to assess the extent to which other penguin species might be affected by gillnetting around the New Zealand mainland. Darby \& Dawson (2000) noted that the Otago Museum holds
9 records of little penguins taken in gillnets. Despite considerable overlap of inshore fisheries and important penguin foraging grounds, the observer programme had not reported any incidents of little penguin bycatch prior to 2016 (Richard \& Abraham 2013), probably due to extremely low observer coverage on gillnetters operating in penguin foraging areas. Efforts to increase independent observer coverage to $2.8 \%$ in 2016 saw 8 little penguins bycaught in a single observed net set for butterfish Odax pullus across a channel in the Stewart-Snares area (Ministry of Primary Industries 2017).

The inshore gillnet ban in southern New Zealand may benefit little penguins in those areas, although exemptions have been granted for net fishing adjacent to key penguin breeding sites (e.g. Motuara Island; Numata et al. 2000, Mattern 2001, Ministry of Primary Industries 2012b, 2015). Most of the rest of New Zealand, where little penguins are widely distributed, has few limits on setting nets.

The rugged and exposed coastlines along most of the Fiordland penguin breeding range largely prevent gillnetting operations (Mattern 2013a). However, many Fiordland penguins forage sympatrically with yellow-eyed penguins in areas where commercial gillnetters operate, especially in the western Foveaux Strait. While only 3 bycatch incidents have officially been reported for this species (Ramm 2010, Ministry of Primary Industries 2017), limited observer coverage makes it difficult to undertake a meaningful assessment of the level of threat.

Snares penguins only breed on the Snares Islands, $200 \mathrm{~km}$ south of the mainland, and are therefore less exposed to gillnetting. However, birds forage to the south of Stewart Island during chick-rearing (Mattern et al. 2009, Mattern 2013b), an area fished by gillnets. The risk of gillnet bycatch for Snares penguins is likely to be lower than for other mainland species, but not negligible.

\section{Australia}

Gillnet fisheries. The majority of reported penguin bycatch incidents in mainland Australia have occurred in gillnets, but data are sparse, with few observer data, making assessment of the bycatch risk to little penguins in Australia difficult. Nevertheless, there are published records of little penguins being entangled and drowned in active or discarded gillnets in Australia, including Victoria (Norman 2000), South Australia (Copley 1996, Knight \& Vainickis 2011) and Tasmania (Stevenson \& Woehler 2007). More sub- 
stantial bycatch events have been recorded, including some 50 dead, entangled little penguins washed ashore on Chalky Island (Bass Strait, Tasmania) in 2015 (Tasmanian Department of Primary Industries, Parks, Water and Environment unpubl. data). A number of other bycatch events involving little penguins have been reported from southeast Tasmania (E. J. Woehler unpubl. data).

Most data on bycatch of little penguins comes from around Phillip Island, southeast Australia $\left(38^{\circ} \mathrm{S}\right.$, $145^{\circ} \mathrm{E}$ ), one of the largest colonies of this species (Nisbet \& Dann 2009, Dann \& Chambers 2013). The majority of little penguins breeding at Phillip Island feed within $15 \mathrm{~km}$ of the coast in northern Bass Strait, where there is considerable overlap with gillnets, or in Port Phillip Bay (Collins et al. 1999, Chiaradia et al. 2007, McCutcheon et al. 2011, Pelletier et al. 2014). Most commercial nets are set at between 40 and 120 m depth (Kailola et al. 1993, Bulman et al. 2006), overlapping with the foraging depths of little penguins that can dive to a max dive depth of $72 \mathrm{~m}$ but normally forage at 20-40 m (Ropert-Coudert et al. 2006, 2009). Recreational gillnetters, where permitted, fish closer inshore than commercial vessels, increasing the risk of interaction, particularly around colonies.

In 2007, 23 penguins were caught in a shark net $15 \mathrm{~km}$ from Queenscliff, Victoria (Phillip Island Nature Parks, unpubl. data), and 25 dead birds were found on Altona Beach in Port Phillip Bay, Victoria, in 2014. Necropsies of the latter concluded that the birds had died after becoming entangled in a gillnet (O'Doherty 2014).

There are 42 records of dead flipper-banded little penguins from Phillip Island reported as 'bird tangled in fishing gear' to the Australian Bird and Bat Banding Schemes (ABBBS) or to the Phillip Island Nature Parks. The relative proportions killed in gillnets or through entanglement in fishing line/snared by hooks are unknown, but both types of mortality have been reported (ABBBS and Research Department, Phillip Island Nature Parks unpubl. data).

In Tasmania, where approximately 10000 gillnets are registered (plus an unknown number of 'many more' unregistered nets), a study undertaking research on gillnets resulted in the bycatch of 5 little penguins, despite the study being designed carefully to avoid seabird interactions. During a recent survey of recreational gillnetters, over a quarter of respondents acknowledged they experienced interaction with seabirds during gillnetting; of these, 39\% reported entanglements of penguins (Lyle et al. 2014). This indicates that bycatch levels may be higher than those reported to date.
While spatial closures have been implemented around some penguin colonies in Tasmania (Lyle et al. 2014), there remain many colonies without such protection. Improving observation of gillnet fisheries to identify bycatch hotspots and inform protected area identification for little penguins, particularly around Tasmania, are thus priority actions.

\section{Antarctica and the Southern Ocean Islands including the CCAMLR area}

The Antarctic and the Southern Ocean islands host, by far, the largest number of penguins compared with the other regions in this review (GarcíaBorboroglu \& Boersma 2013). The region also has the lowest human population and an absence of recreational fishing beyond occasional research efforts at national research facilities. The majority of the fishing effort is larger-scale, particularly trawling, longlining and squid jigging, primarily under the management of the CCAMLR southward of the approximate location of the Antarctic Polar Front. However, this is not the case for all parts of this region, and illegal, unreported and unregulated (IUU) fishing remains a concern for some CCAMLR and non-CCAMLR areas of the Southern Ocean.

Here, we consider penguin bycatch within the CCAMLR area as a single 'unit' (given the broadly uniform fisheries management requirements), with separate assessments for penguin populations outside the Convention area: the Tristan da Cunha group, Amsterdam Island, St. Paul Island, the New Zealand sub-Antarctic islands (Antipodes, Auckland and Campbell) and Macquarie Island.

Tristan da Cunha and Gough Island

The Tristan da Cunha group of islands in the South Atlantic, a UK Overseas Territory, hosts the vast majority of the world's breeding northern rockhopper penguins Eudyptes moseleyi ( 85\% of the global population estimate of 240300 breeding pairs; Cuthbert et al. 2009, Robson et al. 2011, Tristan da Cunha Government and Royal Society for the Protection of Birds unpubl. data).

Longline fisheries. During 2015 and 2016, a single vessel fished for tuna (Thunnus spp.) around Tristan using pelagic longlines. With such a low level of effort, it is believed to have no impact on the northern rockhopper population, although there are no data available on bycatch from this vessel (J. Glass pers. obs.). 
Gillnet fisheries. Bycatch of northern rockhopper penguins in driftnets was recorded from the Tristan exclusive economic zone (EEZ) in the late 1980s/ early 1990s (Ryan \& Cooper 1991). Reports from research vessels, crew members and evidence from a vessel that ran aground in South Africa in 1990 suggest that mortalities from the estimated 160 vessels that operated in the area could have been substantial (Ryan \& Cooper 1991). The 1992 UN Resolution banning high seas driftnets means that legal gillnet fisheries are no longer of concern, though IUU fishing is suspected.

Trawl fisheries and IUU activity. After an exploratory seamount trawl fishery in Tristan da Cunha waters, which operated for 14 d in 2015, a single commercial trawler targeted splendid alfosino Beryx splendens, but mainly caught rosefish Helicolenus mouchezi and cape redfish Sebastes capensis (J. Glass pers. obs.).

No penguins were reported caught, but 6 different types of fishing gear were hauled aboard by the trawler, including jigging gear, gillnets, trawl nets and longlines. Although there are no guarantees as to the provenance of these gears, they were thought to have been used recently based on their condition, and were suspected to have been previously deployed illegally within the Tristan EEZ (J. Glass pers. obs.).

The illegal use of gillnets and trawls is therefore the primary bycatch-related concern for northern rockhopper penguins on Tristan da Cunha, but there is little capacity to assess IUU activity and enforce fisheries regulations for this small group of islands with a large EEZ. In addition, the wintering movements of northern rockhopper penguins (and their overlap with fisheries) are not fully understood.

\section{Amsterdam Island and St. Paul Island}

These 2 islands are French Southern Territories in the southern Indian Ocean and host the remainder of the northern rockhopper penguin population $(\sim 15 \%$; Guinard et al. 1998, Cuthbert 2013, BirdLife International 2017). A St. Paul rock lobster Jasus paulensis fishery is active around the islands, but this is not presently considered to be a threat to penguins (however, historically penguins were used as bait in lobster pots, with suspected population-level effects; Guinard et al. 1998). There is also overlap with longline vessels fishing under Indian Ocean Tuna Commission jurisdiction, but little information is available on bycatch from these vessels (TAAF 2011).
Antipodes, Auckland and Campbell Islands

New Zealand's sub-Antarctic islands host 3 breeding penguin species: yellow-eyed, southern rockhopper E. chrysocome and erect-crested E. sclateri penguins.

Longline and trawl fisheries. Fishing practices in the sub-Antarctic region are principally limited to longlining or trawling. While observer programmes have recorded significant mortality of flying seabirds in New Zealand trawl and longline fisheries in recent years (Ramm 2010, 2012a,b, Dragonfly Data Science 2016), cases of penguin bycatch are practically unknown. One erect-crested penguin was foul hooked in the flipper by a ling (Molva spp.) longliner during hauling, and was subsequently released alive (Ramm 2010).

Without any indication of interactions, the number of estimated fisheries-related fatalities for all subAntarctic penguin species currently stands at 0 for these New Zealand islands (Richard \& Abraham 2013), though observer coverage is variable (broadly lower in inshore trawl compared to offshore fisheries; Dragonfly Data Science 2016).

\section{Macquarie Island}

Macquarie Island holds breeding populations of southern rockhopper, gentoo, king and royal penguins. No recreational gillnetting or trawling is permitted (AFMA 2016a,b).

Longline fisheries. A Patagonian toothfish fishery uses longlines around Macquarie Island (AFMA 2016a). As of the end of 2012, no penguins have been reported as bycatch.

\section{CCAMLR Convention Area}

The CCAMLR Convention Area supports an overwhelming majority of the world's penguins (GarcíaBorboroglu \& Boersma 2013). The area is managed under a regulatory framework that requires fisheries not to expand beyond the limits of the available information on their impacts (CCAMLR 2015a). A number of conservation measures are in place, including specific measures to mitigate against seabird mortality (including seasonal closures and gear restrictions), several marine protected areas (MPAs) and rigorous bycatch reporting procedures (CCAMLR 2015a).

Four main species are targeted across the entire convention area: Patagonian toothfish and Antarctic toothfish Dissostichus mawsoni (13 licensed fisheries, 
largely demersal longliners), mackerel icefish Champsocephalus gunnari (caught using midwater and bottom trawls) and Antarctic krill Euphausia superba (caught using midwater trawls and beam trawls) (CCAMLR 2015a).

There are high levels of observer coverage across the area; icefish and toothfish fisheries have a requirement for $100 \%$ coverage, and target coverage of $50 \%$ in the krill fishery. This makes the Convention Area data-rich compared to other regions reviewed here, and gives high confidence that the bycatch events highlighted below are representative of fleetlevel impacts. Broadly, penguin bycatch is a rare occurrence in the legal CCAMLR fisheries. However, IUU fishing remains a concern in some regions, and is therefore considered separately below. Data for this section were mostly retrieved from CCAMLR Fisheries Reports (available on the CCAMLR website), though some additional, detailed information is included for South Georgia and the South Sandwich Islands.

Longline fisheries. Isolated incidents of penguin bycatch in toothfish fisheries have been recorded. Chilean industrial longliners for Patagonian toothfish recorded penguin bycatch events in CCAMLR Subarea 48.3 (South Georgia) during 1995 (Moreno et al. 1996), with both gentoo and macaroni penguins hooked and released alive. Similarly, a gentoo penguin was captured and released in the longline fisheries around the Kerguelen Islands between 1994 and 1997 (Weimerskirch et al. 2000). In the 1997/98 fishing season, 5 macaroni penguins were foul hooked in the body around the Prince Edward Islands (a South African territory) (Nel et al. 2002). From 2001 to 2003, 1 king, 1 gentoo, 2 macaroni and 1 unidentified penguin were among the anecdotal catch from around Crozet and Kerguelen Islands (French Southern Territories) (CCAMLR 2004, Delord et al. 2005). A single southern rockhopper mortality was recorded in the same area in both the 2005/06 (CCAMLR 2006) and the 2010/11 seasons (CCAMLR 2011).

In 2005, a gentoo penguin was caught in a demersal longline in the South Georgia and South Sandwich Islands Maritime Zone, although on this occasion it was entangled in the line. In 2009, a chinstrap penguin Pygoscelis antarctica was injured in the exploratory toothfish fishery around the South Sandwich Islands (CCAMLR 2013). A single penguin (species not specified) was hooked in the foot in 2014, but this bird was released alive and in good condition (K. Ross pers comm.). No other penguin bycatch incidents were observed in this area between 2001 and 2014.
The most recent recorded mortality comes from the toothfish fishery around Heard Island (Australian EEZ) in 2014, where 1 southern rockhopper was killed (CCAMLR 2014).

Trawl fisheries. The only penguin bycatch recorded in CCAMLR mackerel icefish trawl fisheries was in 2008, when 2 king penguins were caught around South Georgia. There are only 2 active mackerel icefish fisheries in the region: the South Georgia fishery (total allowable catch of $2074 \mathrm{t}$ in 2016/17), and a smaller fishery around Heard Island (total allowable catch of $482 \mathrm{t}$ in 2015/16 season; CCAMLR 2016a).

The last record of penguin (species unknown) bycatch in krill trawlers was in 2007, but it is not known whether this interaction occurred during active fishing or on retrieval of the gear. Although observer coverage in this fishery is lower than in other CCAMLR fisheries, it is not suspected that penguin bycatch is an issue. Postulated reasons for the low penguin bycatch in this fishery have centred on the slow trawling speeds (2-3 knots) and the potential for some seal bycatch mitigation devices to allow penguins to escape (K. Reid pers. comm.).

IUU fisheries. Although IUU fishing is believed to have decreased markedly since the 1990s, when illegal catch was estimated to be 6 times that of legal catch in the Convention Area (CCAMLR 2016b), it continues to occur in some CCAMLR regions. It can be safely assumed that these vessels will not report bycatch and regularly use gear types that are not permitted in the CCAMLR area, particularly gillnets, which pose a significant threat to penguins, especially as nets are reported to be up to $25 \mathrm{~km}$ in length (CCAMLR 2015b). This means that penguin bycatch data are not available, and it is difficult to make estimates for the entire CCAMLR area without observations (CCAMLR 2008).

Overall, current penguin bycatch in legal fisheries within the Convention area is not believed to be a major threat to Antarctic and Southern Ocean penguin populations. However, IUU fishing, particularly when large gillnets are used, is a concern.

\section{DISCUSSION}

Some level of bycatch has been recorded for 14 of the 18 penguin species in 4 different gear types (see Table 2). Despite the above assessments being reliant on minimal published data, some broad initial findings are clearly identifiable with respect to species conservation and fisheries management. The impact of bycatch is not of equal concern for all species 
within a region, varying according to species' foraging ecologies and behaviours, fishing effort and the types of gear that predominate within penguin foraging ranges. Because of this, we focus firstly on gear for which mitigation measures are urgently needed and secondly on the species towards which limited conservation resources should be directed.

\section{Gear types of concern}

This review highlights gillnets, and to a lesser extent trawls, as the fishing gear types that most commonly lead to penguin bycatch mortality (Table 1). While interactions have been recorded with longlines, the low number of recorded mortalities (with relatively high observer effort, particularly in CCAMLR fisheries) suggests that bycatch in this gear type is a relatively rare event for all species of penguin.

Penguin entanglements in gillnets are almost inevitable given their pursuit diving foraging behaviour and the virtual invisibility of modern monofilament nylon netting when deployed underwater (Martin \& Crawford 2015). Bycatch mortality in gillnets has been recorded in Magellanic, Humboldt, Galápagos, African, northern rockhopper, little, Fiordland and yellow-eyed penguins.

Penguins are capable of deep dives $(90 \mathrm{~m}$ by Magellanic penguins, Walker \& Boersma 2003; $130 \mathrm{~m}$ by yellow-eyed penguins, Moore et al. 1995), but as airbreathers, a significant amount of time is spent at the surface. Additionally, both Magellanic and Humboldt penguins feed on pelagic prey (Frere et al. 1996, Herling et al. 2005) which is a potential reason for the higher bycatch rates recorded for these species in surface-set driftnets compared to bottom-set gillnets (Majluf et al. 2002, Cardoso et al. 2011). In contrast, yellow-eyed penguins are predominantly benthic foragers ( $87 \%$ of dives; Mattern et al. 2007) and thus are caught in bottom-set gillnets. Gillnets pose a significant threat to penguins irrespective of the depth at which they are deployed, and are therefore the fishing gear type of greatest concern.

Trawl interactions have been primarily recorded for Magellanic penguins, but both gentoo and king penguins have also been captured. While these interactions are subtly different among species, they primarily occur during hauling. Magellanic penguins are caught as they attempt to forage on smaller fish dropping out of the net as it is hauled (GonzálezZevallos \& Yorio 2006), and some of the gentoo penguins caught in the Falkland Islands were actively feeding on discards (Roux et al. 2012), suggesting that discard management measures could mitigate against such bycatch, at least for these species.

The direct impact of purse seine fisheries on penguins has been subject to almost no research, but the limited amount of data from Chile suggest that, at least there (where effort is high), the issue of penguin (and other seabird) bycatch warrants further investigation (ATF-Chile unpubl. data).

\section{Species of concern}

To further identify priorities for action on bycatch, the species that are presently most at-risk from capture in fisheries are highlighted. Note that this is based on present scenarios, with limited available literature on bycatch; these categorisations may change with new information and changing fishing effort or species distributions.

High risk

The 3 species for which there is a substantive amount of evidence of fisheries bycatch are Humboldt, Magellanic and yellow-eyed penguins. The distributions and gear types of concern for these species are shown in Fig. 3.

Magellanic penguins are the best-researched species with regard to bycatch (Gandini et al. 1999, Yorio \& Caille 1999, González-Zevallos \& Yorio 2006, Cardoso et al. 2011, González-Zevallos et al. 2011, Marinao et al. 2014). This species is listed as Near Threatened, owing to declining trends in the Argentinean breeding colonies that represent the majority of the estimated global population (Table 2; BirdLife International 2017). So while no single fishery is thought to have population-level impacts on the species, this trend highlights the concern of potential cumulative effects of bycatch in various trawl and gillnet fisheries from breeding colonies in southern Chile and central/southern Argentina to non-breeding grounds in Uruguayan and Brazilian waters (Schlatter et al. 2009, Pütz et al. 2011, Stokes et al. 2014). Further, the evidence from some studies (Cardoso et al. 2011, Marinao et al. 2014, Gianuca et al. 2017) that bycatch is predominantly comprised of adults increases the possibility that bycatch impacts are significant at a population level.

Although fewer data are available on Humboldt penguin bycatch, the IUCN Red List status of this species (Vulnerable, owing to an overall reduction in the number of breeding colonies indicating an ongo- 


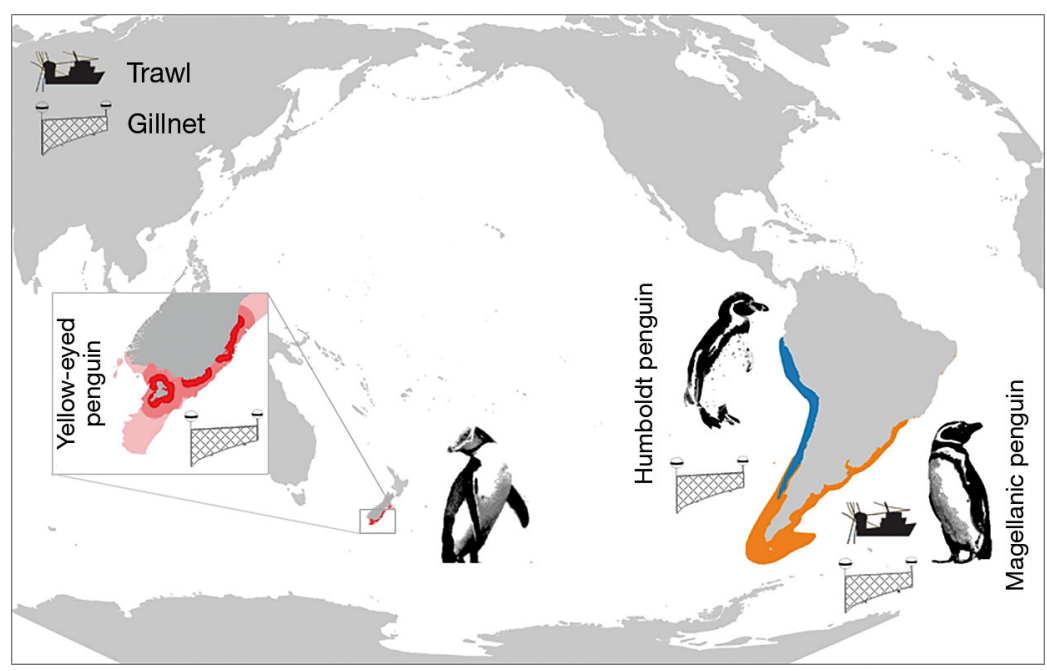

Fig. 3. At-sea distribution of the 3 penguin species for which bycatch is currently of most concern, and the fishing gear types that birds interact with most. These ranges represent priority sites for conservation action on penguin bycatch. For yellow-eyed penguin, dark red areas denote foraging range in a 'normal' breeding season, with the lighter shade representing expanded range for breeding birds when food supply is poorer. The pink shading denotes the non-breeding foraging range, limited by the $150 \mathrm{~m}$ depth contour. Blue shading: breeding and non-breeding range for Humboldt penguins; orange shading: breeding and non-breeding range for Magellanic penguins. Source: BirdLife International and Eudyptes Ecoconsulting

ing rapid decline; BirdLife International 2017) and the high number of artisanal fisheries using gillnets within the species' core range in Chile and Peru (Goya et al. 2011) puts Humboldt penguins at risk. In light of the apparently heightened risk from driftnets (versus bottom-set nets; Majluf et al. 2002), priority should be afforded to collecting data in these fisheries operating within at least $35 \mathrm{~km}$ of key colonies (Culik \& Luna-Jorquera 1997, Luna-Jorquera \& Culik 1999).

Bycatch mortality is of greatest concern for the Endangered yellow-eyed penguin (Darby \& Dawson 2000, Ellenberg \& Mattern 2012, Mattern et al. 2017). The population is decreasing and is now thought to number fewer than 400 pairs for the New Zealand mainland population (only 216 nests found during 2015/16 searches; M. Young pers. comm.). Current by-

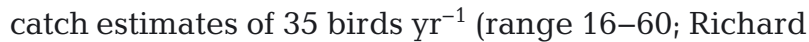
\& Abraham 2015) are potentially an underestimate due to the lack of independent observer coverage on commercial gillnetters operating in important penguin foraging areas. However, given the species' precarious situation, even low numbers of bycaught penguins will contribute to the species' demise. Gillnet effort peaks in summer, which coincides with the yellow-eyed penguin breeding season. The loss of 1 parent usually results in breeding failure (Darby \&
Dawson 2000), and the surviving bird will generally skip at least 1 breeding season following the loss of its partner (Setiawan et al. 2005), further exacerbating the impact of bycatch.

\section{Moderate risk}

Fiordland, Galápagos and little penguins are considered to be moderately susceptible to bycatch at present. While only 3 Fiordland penguins have been officially recorded as bycatch, recent evidence suggests that bycatch occurs more regularly, particularly off Stewart Island. Limited observer coverage means there is considerable uncertainty about potential impacts. Given the foraging overlaps with commercial gillnetters and shared foraging grounds with yellow-eyed penguins, further observer effort is required to better determine the risks for this species.

There are no legal fisheries operating around the Galápagos Islands impacting Galápagos penguins, but illegal gillnetting is suspected to occur, and this is of some concern, especially as the species is listed as Endangered (BirdLife International 2017).

Little penguins are susceptible to capture in gillnets, but with few observer data and a relatively secure conservation status (Least Concern, BirdLife International 2017), we have ranked the species as moderately susceptible, pending further studies. However, if little penguins are split into separate New Zealand and Australian species (Grosser et al. 2015), this would increase conservation concern and therefore the relative priority of the bycatch issue.

\section{Low risk}

Given the high level of observer coverage in CCAMLR fisheries and low levels of bycatch recorded, the Antarctic species (king, gentoo, chinstrap, emperor and Adelie penguins) can be considered of lowest concern with regard to bycatch; indeed, the latter 2 species have never been recorded as bycatch. Also of lower concern are Snares and royal penguins, for which there are no records of incidental captures in fisheries, most likely linked to the remote locations of colonies and restricted ranges (but note that 
Table 2. Recorded penguin bycatch in fisheries. IUCN status and population size estimate from BirdLife International (2017). EN: Endangered, VU: Vulnerable, NT: Near Threatened, LC: Least Concern. Gear types are G: gillnet, LL: longline, PS: purse seine, T: trawl. Grey boxes indicate that country is not part of that species' range

\begin{tabular}{|c|c|c|c|c|c|c|c|c|c|c|c|c|c|}
\hline \multirow[b]{2}{*}{ Species } & \multirow[b]{2}{*}{ 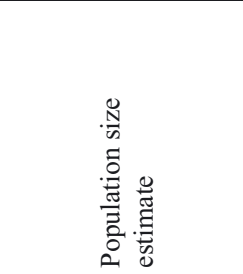 } & \multicolumn{8}{|c|}{ South America } & \multirow{2}{*}{$\begin{array}{c}\begin{array}{c}\text { Southern } \\
\text { Africa }\end{array} \\
\end{array}$} & \multicolumn{2}{|c|}{ Australasia } & \multirow{2}{*}{ 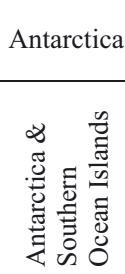 } \\
\hline & & $\begin{array}{l}\text { 志 } \\
\text { 吾 } \\
\text { Z } \\
\text { 己. }\end{array}$ & 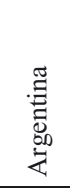 & 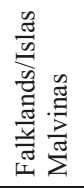 & 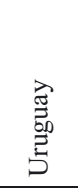 & $\begin{array}{l}\overline{\widetilde{N}} \\
\bar{n}\end{array}$ & $\stackrel{\bullet}{\exists}$ & ב & $\begin{array}{l}\overrightarrow{0} \\
\frac{\pi}{\tilde{J}} \\
\tilde{J} \\
\tilde{I}\end{array}$ & & $\begin{array}{l}\vec{Z} \\
\text { ज्ञ } \\
\text { J } \\
\text { z } \\
\text { z } \\
z\end{array}$ & 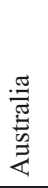 & \\
\hline Magellanic & $1.1-1.6$ million pairs & NT & $\mathrm{T} ; \mathrm{G}$ & $\mathrm{T}$ & $\mathrm{T}$; PS & G & G; PS & & & & & & \\
\hline Galápagos & 1200 ind. & EN & & & & & & & G & & & & \\
\hline Humboldt & 32000 ind. & $\mathrm{VU}$ & & & & & G & G & & & & & \\
\hline African & 50000 ind. & $\mathrm{EN}$ & & & & & & & & G & & & \\
\hline Little & 469760 ind. & $\mathrm{LC}$ & & & & & & & & & G & G & \\
\hline $\begin{array}{l}\text { Southern } \\
\text { rockhopper }\end{array}$ & 2500000 ind. & VU & & & & & LL & & & & & & LL \\
\hline $\begin{array}{l}\text { Northern } \\
\text { rockhopper }\end{array}$ & 240300 pairs & EN & & & & & & & & & & & G \\
\hline Macaroni & 6.3 million pairs & VU & & & & & & & & & & & LL \\
\hline Fiordland & $5500-7000$ ind. & VU & & & & & & & & & G & & \\
\hline Erect-crested & 150000 ind. & EN & & & & & & & & & & & LL \\
\hline Yellow-eyed & 1700 breeding pairs & EN & & & & & & & & & G & & \\
\hline Chinstrap & 4 million pairs & LC & & & & & & & & & & & LL \\
\hline Gentoo & 774000 ind. & $\mathrm{LC}$ & & $\mathrm{T} ; \mathrm{LL}$ & & & & & & & & & LL \\
\hline King & 1.6 million pairs & $\mathrm{LC}$ & & $\mathrm{T}$ & & & & & & & & & LL; T \\
\hline
\end{tabular}

Snares penguins do forage in areas with active gillnet fisheries; Mattern et al. 2009, Mattern 2013b).

While erect-crested, macaroni and northern and southern rockhopper penguins have been recorded as bycatch, similarly to Snares and royal penguins, the remote, restricted locations of colonies and limited presence of these species in areas of high coastal fishing effort suggests that these species are currently of least concern. With no evidence of trawl interactions and gillnet exclusions around colonies (South Africa) or across the coast (Namibia), the risk of bycatch for African penguins is presently low, though this would change if gillnet restrictions were lifted, given previous bycatch events in this gear.

\section{Importance of bycatch compared to other threats for the most susceptible species}

Poor observer coverage in some areas, including some commercial inshore fisheries operating in key penguin foraging areas, impedes the assessment of the relative importance of fisheries-related mortality against other threats. However, given limited available conservation resources, some comparison gives context and aids prioritisation. Climate change is likely to affect all of these species, albeit in different ways (García-Borboroglu \& Boersma 2013, Trathan et al. 2015, Mattern et al. 2017). In order to improve resilience of penguin populations in the face of climate change, other threats need to be substantially reduced, and incidental mortality in fishing gear is one threat that can be addressed immediately.

The greatest threats to Magellanic penguins are at sea (García-Borboroglu \& Boersma 2013), and of these, bycatch is perhaps the most significant. No industrial fisheries are currently in competition with Magellanic penguins for the same prey species (contrary to Humboldt and African penguins; García-Borboroglu \& Boersma 2013). Oil spills have been of concern (García-Borboroglu et al. 2008), and although they have decreased in frequency in recent years, they should still be considered with fisheries bycatch in terms of potential population level effects.

The greatest threat to Humboldt penguins is believed to be competition with fisheries for Peruvian 
anchoveta Engraulis ringens (Herling et al. 2005), particularly in combination with impacts on prey resulting from more frequent El Niño-Southern Oscillation events (Culik et al. 2000). Humboldt penguins are vulnerable to unregulated tourism, but its impacts have not been quantified at a population level (Ellenberg et al. 2006). Furthermore, some Humboldt penguins are taken for illegal consumption and bait both in Chile and Peru (P. McGill pers. comm.). AlfaroShigueto et al. (2010) noted that mortality of Humboldt penguins could be exacerbated by the retention of incidentally captured penguins for human consumption, and Trathan et al. (2015) mentioned egg collection as a threat. As this review has documented, Humboldt penguins are bycaught in gillnets (Majluf et al. 2002, Pro Delphinus unpubl. data). As many vessels use this gear within the Humboldt penguin foraging range (Goya et al. 2011), the region is clearly a priority for further research and mitigation, in association with ecosystem-based management of the anchoveta fishery and ensuring that tourism is carefully managed at colonies.

The situation is complex for yellow-eyed penguins; the population is small and decreasing, and is facing a wide spectrum of threats (Seddon et al. 2013, Mattern et al. 2017), including sensitivity to human disturbance (Ellenberg et al. 2007, 2013), vulnerability to disease outbreaks and marine pollution, the loss of mature coastal forest as breeding habitat, and predation by introduced mammals (Seddon et al. 2013). Furthermore, recent research shows that as sedentary benthic foragers, yellow-eyed penguins are particularly vulnerable to climate change (Mattern et al. 2017).

Whereas terrestrial threats are reasonably well understood and managed, threats at sea require urgent attention. There are marked natural inter-annual variations in food availability affecting reproductive success and survival, with $33 \%$ of population variability explained by ocean warming alone (Mattern et al. 2017). The impact of climate change is expected to intensify, making populations less resilient to nonclimate related impacts. In addition to bycatch in gillnets, there is concern about the potential indirect effects of habitat degradation from commercial dredging (Browne et al. 2011) and bottom trawl fisheries (Mattern et al. 2013) impacting on prey species, and the indirect competition from overfishing of spawning stocks (Ellenberg \& Mattern 2012). Similar to bycatch, these other fisheries-related threats are poorly quantified. Of the at-sea threats, reducing bycatch mortality of yellow-eyed penguins is the most feasible action to improve the resilience of this Endangered species.

\section{RECOMMENDATIONS}

The following recommendations are offered to reduce penguin bycatch and to provide the critical data required for evidence-based management.

\section{Species-specific monitoring and bycatch estimates}

Given the limited available data on penguin bycatch, and the potential threat posed to the 3 priority species listed above, there is a strong case for improved bycatch monitoring in key fisheries. Independent monitoring of fisheries operating in penguin foraging areas is essential to quantify actual bycatch mortality. Although limited resources may reduce the ability to monitor fleets via costly observer programmes, bycatch of other taxa (i.e. cetaceans) has been successfully, and more cheaply, monitored by video camera (Kindt-Larsen et al. 2012). The use of electronic monitoring in surface longline fisheries in Australia has significantly modified fisher behaviour with respect to logbook reporting, including seabird bycatch (Larcombe et al. 2016). The small size of many gillnet vessels means there are difficulties in placing physical observers on board, further strengthening the case for higher levels of electronic monitoring.

Monitoring priorities for the 3 most at-risk species are listed in Box 1 below.

In addition, significant data gaps exist for species for which single instances of bycatch have been recorded, meriting further investigation. Specifically, the extent of gillnet use in South Africa and Namibia and the risk to African penguins in these fisheries must be addressed. Monitoring of gillnet fisheries is required in Bass Strait, Australia, in light of the number of little penguin captures. Additionally, the conservation status of the Galápagos penguin warrants closer monitoring of illegal gillnet fisheries.

\section{Technical mitigation measures}

Effective technical mitigation measures are yet to be fully developed to reduce sub-surface seabird interactions with gillnet and trawl fisheries. Some measures have shown promise, including thicker, white meshes in the upper sections of driftnets and the use of acoustic 'pingers' to deter auks (Melvin et al. 1999). Recent research has proposed the deployment of black and white panels to alert birds to gillnets (Martin \& Crawford 2015), and tests of LED lights clipped along the headline of gillnets have 
Box 1. Bycatch monitoring priorities for fisheries affecting susceptible penguins

\begin{abstract}
Humboldt penguin:
- Peruvian driftnet fisheries, particularly those operating close to the Punta San Juan de Marcona, Isla Santa Rosa and Isla San Juanito colonies, the largest colonies in Peru, and other fishing ports located near nesting colonies; cumulative bycatch assessment of Humboldt Current net fisheries, including driftnets.

- Chilean gillnet fisheries, operating along the Humboldt Current, particularly between $18^{\circ}$ and $42^{\circ} \mathrm{S}$, which overlaps with Humboldt penguin colonies and mixed colonies with Magellanic penguins.

- Chilean purse seine fisheries, especially around important breeding and non-breeding routes for this species in central Chile (e.g. Valparaíso, $\left.33^{\circ} \mathrm{S}\right)$.

Magellanic penguin:

- Gillnet vessels in Argentina, Uruguay, south-central Chile and southern Brazil, particularly the bluefish fishery.

- Freezer red shrimp and ice trawl vessels in Argentina and the hake trawl fishery in Uruguay.

- Chilean purse seine fisheries, especially around important breeding and non-breeding routes for this species between central Chile (Valparaíso, $33^{\circ} \mathrm{S}$ ) and southcentral Chile $\left(41^{\circ} \mathrm{S}\right)$.

- Undertake a cumulative bycatch assessment for all of these fisheries, including consideration of impacts to birds from the Falkland Islands (Islas Malvinas) breeding population.

Yellow-eyed penguin (also relevant for little, Fiordland and Snares penguins):

- A substantial increase in independent observer coverage (ideally $100 \%$ ) for at least 5 yr on commercial gillnetting vessels operating in important yellow-eyed penguin foraging areas in North Otago, around the Otago Peninsula, in the Catlins and around Stewart Island and outliers, as identified by Ellenberg \& Mattern (2012), which should also pick up any Fiordland penguin mortality, particularly around Stewart Island. In the face of limited funds, independent observer efforts may be concentrated on nets set for demersal fish during January to March in each season. Electronic monitoring should be deployed in all commercial gillnet fisheries as a priority.
\end{abstract}

reduced turtle (Wang et al. 2013, Ortiz et al. 2016) and seabird (Mangel et al. unpubl. data) bycatch. Adjusting the twine colour of surface gillnets (in less turbid waters) may also have some utility (Hanamseth et al. in press). Further research into potential technical measures should prioritise fisheries with known penguin interactions.

\section{Site identification and spatial/temporal closures}

In the absence of established mitigation measures, and given the elevated conservation concern for many penguin species, identification of the most important at-sea sites for penguins (e.g. via tracking where pos- sible or using foraging radii around colonies) will help to identify where penguin foraging areas overlap with fisheries and inform MPAs, with appropriate spatial or temporal fisheries closures. The higher rates of Magellanic penguin bycatch observed closer to shore for colonies in Argentina (Yorio et al. 2010, GonzálezZevallos et al. 2011, Marinao et al. 2014) emphasises the potential for spatial approaches. Seasonal or finerscale temporal closures in particular may have potential for Magellanic (González-Zevallos et al. 2011) and Humboldt penguins (Majluf et al. 2002), and could take advantage of the existing system of MPAs in the region.

The temporal/spatial fisheries management and the creation of MPAs is particularly urgent for yellow-eyed penguin, the most threatened species considered here. Eighteen important sites have already been identified (Forest \& Bird 2015); yet, thus far, no MPAs have been established in important yelloweyed penguin foraging areas.

The majority of the 290 Important Bird and Biodiversity Areas identified for penguins to date are terrestrial (BirdLife International 2016), making the identification of at-sea areas particularly important to inform fisheries and other conservation management at sea.

Acknowledgements: This review was conceived at a bycatch workshop at the 8th International Penguin Conference in Bristol, UK, and we are grateful to participants at the workshop for their suggestions, data and comments. The review greatly benefited from the insightful comments of P. Dee Boersma, Luis A. Cabezas, Pablo García-Borboroglu, F. Hernán Vargas, Dave Houston, Tamara Martínez, Patty McGill, Bruce McKinlay, Godfrey Merlen, Jaime Ojeda, Norman Ratcliffe, Philip J. Seddon, Bryan Wallace, Ralph Vanstreels and Oliver Yates, as well as 2 reviewers. Thanks to the Galápagos National Park Directorate, Charles Darwin Foundation and donors for data on Galápagos penguins. This research did not receive any specific grant from funding agencies in the public, commercial or not-for-profit sector.

\section{LITERATURE CITED}

AFMA (Australian Fisheries Management Authority) (2016a) Macquarie Island toothfish fishery. www.afma.gov.au/ fisheries/macquarie-island-fishery/ (accessed 5 May 2016) AFMA (2016b) Heard Island and McDonald Islands fishery. www.afma.gov.au/fisheries/heard-island-mcdonald-islandfishery/ (accessed 5 May 2016)

Alfaro-Shigueto J, Mangel JC, Pajuelo M, Dutton PH, Seminoff JA, Godley BJ (2010) Where small can have a large impact: structure and characterization of small-scale fisheries in Perú. Fish Res 106:8-17

Anderson ORJ, Small CJ, Croxall JP, Dunn EK, Sullivan BJ, Yates O, Black A (2011) Global seabird bycatch in longline fisheries. Endang Species Res 14:91-106 
Andrews J, Hough A, Medley P (2014) Falkland Islands toothfish longline fishery. Public Certification Report. https:// fisheries.msc.org/en/fisheries/falkland-island-toothfish/ @@assessments (accessed 24 Feb 2016)

Araya B (1988) Status of the Humboldt penguin in Chile following the 1982-83 El Niño. Spheniscid Penguin Newsl $1: 8-10$

Asamblea Nacional (2015) Ley Orgánica de Régimen Especial de la Provincia de Galápagos. Asamblea Nacional, República del Ecuador, Quito

Barton J (2002) Fisheries and fisheries management in Falkland Islands Conservation Zones. Aquat Conserv 12: 127-135

BirdLife International (2016) World Bird Database. www. birdlife.org/datazone/home (accessed 22 Feb 2016)

BirdLife International (2017a) IUCN Red List for birds. http:// datazone.birdlife.org/species/search (accessed 18 Aug 2017)

BirdLife International (2017b) BirdLife taxonomic checklist Version 9.1 (updated June 2017). http://datazone.birdlife. org/species/taxonomy (accessed 30 June 2017)

Boessenkool S, Waters J, Seddon P (2009) Multilocus assignment analyses reveal multiple units and rare migration events in the recently expanded yellow-eyed penguin (Megadyptes antipodes). Mol Ecol 18:2390-2400

Brothers NP, Cooper J, Løkkeborg S (1999) The incidental catch of seabirds by longline fisheries: worldwide review and technical guidelines for mitigation. FAO Fisheries Circular No. 937. FAO, Rome

Browne T, Lalas C, Mattern T, van Heezik Y (2011) Chick starvation in yellow-eyed penguins: evidence for poor diet quality and selective provisioning of chicks from conventional diet analysis and stable isotopes. Austral Ecol 36:99-108

Bull LS (2007) Reducing seabird bycatch in longline, trawl and gillnet fisheries. Fish Fish 8:31-56

Bulman C, Condie S, Furlani D, Cahill M, Klaer N, Goldsworthy S, Knuckey I (2006) Trophic dynamics of the eastern shelf and slope of the South East fishery: impacts of and on the fishery. Final Report for Fisheries Research and Development Corporation. Project No. 2002/028. CSIRO Marine and Atmospheric Research, Hobart

Cardoso LG, Bugoni L, Mancini PL, Haimovici M (2011) Gillnet fisheries as a major mortality factor of Magellanic penguins in wintering areas. Mar Pollut Bull 62:840-844

CCAMLR (Commission for the Conservation of Antarctic Living Marine Resources) (2004) Report of the Working Group on Fish Stock Assessment 2003-04. Hobart, Australia, 11 to 22 October 2004. Document number WGFSA-04. CCAMLR, Hobart

CCAMLR (2006) Report of the Working Group on Fish Stock Assessment 2005-06. Hobart, Australia, 9 to 20 October 2006. Document number WG-FSA-06. CCAMLR, Hobart

CCAMLR (2008) Fisheries management and conservation under conditions of uncertainty 2008. http://archive. ccamlr.org/pu/e/e_pubs/sr/08/i07.pdf

CCAMLR (2011) Fishery Report: Dissostichus eleginoides Kerguelen Islands (Division 58.5.1). Hobart, Australia, 10 to 21 October 2011. CCAMLR, Hobart

CCAMLR (2013) Fishery Report 2013: exploratory fishery for Dissostichus spp. in the South Sandwich Islands (Subarea 48.4). Hobart, Australia, 7 to 18 October 2013. CCAMLR, Hobart

CCAMLR (2014) Fishery Report 2014: Dissostichus eleginoides Heard Island Australian EEZ (Division 58.5.2).
Hobart, Australia, 6 to 17 October 2014. CCAMLR, Hobart CCAMLR (2015a) Commission for the Conservation of Antarctic Living Marine Resources. https://www.ccamlr. org/en/fisheries/regulatory-framework (accessed 18 Sep 2015)

CCAMLR (2015b) New Zealand initiates action against IUU vessels in the Southern Ocean. https://www.ccamlr.org/ en/news/2015/new-zealand-initiates-action-against-iuuvessels-southern-ocean (accessed 23 Sep 2015)

CCAMLR (2016a) Conservation measures. https://www. ccamlr.org/en/conservation-and-management/browseconservation-measures\# (accessed 11 Apr 2016)

* CCAMLR (2016b) Illegal, unreported and unregulated (IUU) fishing. https://www.ccamlr.org/en/compliance/illegalunreported-and-unregulated-iuu-fishing (accessed 24 Aug 2016)

KChiaradia A, Ropert-Coudert Y, Kato A, Mattern T, Yorke J (2007) Diving behaviour of little penguins from four colonies across their whole distribution range: bathymetry affecting diving effort and fledging success. Mar Biol 151:1535-1542

Collins M, Cullen JM, Dann P (1999) Seasonal and annual foraging movements of little penguins. Wildl Res 26: 705-721

Copley PB (1996) The status of seabirds in South Australia: a review. In: Ross GJB, Weaver K, Greig JC (eds) The status of Australia's seabirds. Proceedings of the National Seabird Workshop, Canberra, p 139-180

Crawford RJM, Altwegg R, Barham BJ, Barham PJ and others (2011) Collapse of South Africa's penguins in the early 21st century. Afr J Mar Sci 33:139-156

Crawford RJM, Kemper J, Underhill LG (2013) African penguin (Spheniscus demersus). In: García-Borboroglu P, Boersma D (eds) Penguins: natural history and conservation. University of Washington Press, Seattle, WA, p 305-319

Croxall JP, Butchart SHM, Lascelles B, Stattersfield AJ, Sullivan B, Symes A, Taylor P (2012) Seabird conservation status, threats and priority actions: a global assessment. Bird Conserv Int 22:1-34

* Culik BM, Luna-Jorquera G (1997) Satellite tracking of Humboldt penguins (Spheniscus humboldti) in northern Chile. Mar Biol 128:547-556

Culik B, Hennicke J, Martin T (2000) Humboldt penguins outmanoeuvring El Niño. J Exp Biol 203:2311-2322

Cuthbert R (2013). Northern rockhopper penguin Eudyptes moseleyi. In: García-Borboroglu P, Boersma D (eds) Penguins: natural history and conservation. University of Washington Press, Seattle, WA, p 131-143

* Cuthbert RJ, Cooper J, Burle MH, Glass CJ and others (2009) Population trends and conservation status of the northern rockhopper penguin Eudyptes moseleyi at Tristan da Cunha and Gough Island. Bird Conserv Int 19:109-120

*Dann P, Chambers L (2013) Ecological effects of climate change on little penguins Eudyptula minor and the potential economic impact on tourism. Clim Res 58:67-79

Darby J, Dawson S (2000) Bycatch of yellow-eyed penguins (Megadyptes antipodes) in gillnets in New Zealand waters 1979-1997. Biol Conserv 93:327-332

Delord K, Gasko NW, Weimerskirch H, Barb raud C, Micol T (2005) Seabird mortality in the Patagonian toothfish longline fishery around Crozet and Kerguelen Islands, 2001-2003. CCAMLR Sci 12:53-80

Domingo A, Forselledo R, Jimenez S (2015) Revisión de planes de acción nacional para la conservación de aves 
marinas y condrictios en las pesquerías Uruguayas. Dirección Nacional de Recursos Acuáticos, Montevideo

Dragonfly Data Science (2016) https://psc.dragonfly.co.nz/ (accessed 19 May 2016)

Duffy DC, Hays C, Plenge MA (1984) The conservation status of Peruvian seabirds. In: Croxall JP, Evans PGH, Schreiber RW (eds) Status and conservation of the world's seabirds. Tech Publ No 2. International Council for Bird Preservation, Cambridge, p 245-259

Ellenberg U, Mattern T (2012) Yellow-eyed penguin: review of population information. Department of Conservation, Marine Conservation Services Programme, Wellington

* Ellenberg U, Mattern T, Seddon PJ, Luna-Jorquera G (2006) Physiological and reproductive consequences of human disturbance in Humboldt penguins: the need for speciesspecific visitor management. Biol Conserv 133:95-106

Ellenberg U, Setiawan AN, Cree A, Houston D, Seddon PJ (2007) Elevated hormonal stress response and reduced reproductive output in yellow-eyed penguins exposed to unregulated tourism. Gen Comp Endocrinol 152:54-63

Ellenberg U, Mattern T, Seddon PJ (2013) Heart rate responses provide an objective evaluation of human disturbance stimuli in breeding birds. Conserv Physiol 1: $\cot 013$

Forest \& Bird (2015) New Zealand seabirds: sites on land, coastal sites and islands. The Royal Forest \& Bird Protection Society of New Zealand, Wellington. http://www. forestandbird.org.nz/important-bird-areas (accessed 19 May 2016)

Frere E, Gandini PA, Lichtschein V (1996) Variación latitudinal en la dieta del pingüino de Magallanes (Spheniscus magellanicus) en la costa patagónica, Argentina. Ornitol Neotrop 7:35-41

Gandini PA, Frere E, Pettovello AD, Cedrola PV (1999) Interaction between Magellanic penguins and shrimp fisheries in Patagonia, Argentina. Condor 101:783-789

García-Borboroglu P, Boersma PD, Reyes L, Skewgar E (2008) Petroleum pollution and penguins: marine conservation tools to reduce the problem. In: Hofer TN (ed) Marine pollution: new research. Nova Science Publishers, New York, NY, p 339-356

García-Borboroglu P, Boersma PD (eds) (2013) Penguins: natural history and conservation. University of Washington Press, Seattle, WA

Gianuca D, Phillips RA, Townley S, Votier SC (2017) Global patterns of sex- and age-specific variation in seabird bycatch. Biol Conserv 205:60-76

González-Zevallos D, Yorio P (2006) Seabird use of discards and incidental captures at the Argentine hake trawl fishery in the Golfo San Jorge, Argentina. Mar Ecol Prog Ser 316:175-183

*González-Zevallos D, Yorio P, Svagelj WS (2011) Seabird attendance and incidental mortality at shrimp fisheries in Golfo San Jorge, Argentina. Mar Ecol Prog Ser 432: 125-135

Goya E, Baker B, Papworth W, Favero M (2011) Caracterización de las pesquerías artesanales en Sudamérica y su impacto sobre albatros y petreles. Fourth Meeting of the Seabird Bycatch Working Group of the Agreement on the Conservation of Albatrosses and Petrels. SBWG-4 Doc No. 22. https://www.acap.aq/en/documents/workinggroups/seabird-bycatch-working-group/seabird-bycatchwg-meeting-4/sbwg4-meeting-documents/1345-sbwg-4doc-22-artisanal-fisheries-in-south-america/file

* Grosser S, Burridge CP, Peucker AJ, Waters JM (2015) Coa- lescent modelling suggests recent secondary-contact of cryptic penguin species. PLOS ONE 10:e0144966

Guinard E, Weimerskirch H, Jouventin P (1998) Population changes and demography of the northern rockhopper penguin on Amsterdam and Saint Paul Islands. Colon Waterbirds 21:222-228

Hanamseth R, Baker GB, Sherwen S, Hindell M, Lea MA (in press) Assessing the importance of net colour as a seabird bycatch mitigation measure in gillnet fishing. Aquatic Conserv: Mar Freshw Ecosyst 2017, https://doi. org/10.1002/aqc. 2805

* Harris MP (1973) The Galápagos avifauna. Condor 75: 265-278

Hays C (1984) The Humboldt penguin in Peru. Oryx 18: 92-95

* Herling R, Culik BM, Hennicke JC (2005) Diet of the Humboldt penguin (Spheniscus humboldti) in northern and southern Chile. Mar Biol 147:13-25

Hocken AG (2005) Necropsy findings in yellow-eyed penguins (Megadyptes antipodes) from Otago, New Zealand. N Z J Zool 32:1-8

IBAMA/CEPERG (2009) Desembarque de pescado no Rio Grande do Sul: 2008. Instituto Brasileiro do Meio Ambiente e dos Recursos Naturais Renováveis: Centro de Pesquisa e Gestão dos Recursos Pesqueiros Lagunares e Estuarinos, Projeto Estatística Pesqueira, Rio Grande

Kailola PJ, Williams MJ, Stewart PC, Reichelt RE, McNee A, Grieve C (1993) Australian fisheries resources. Fisheries Research and Development Corporation, Canberra

Kindt-Larsen L, Dalskov J, Stage B, Larsen F (2012) Observing incidental harbour porpoise Phocoena phocoena bycatch by remote electronic monitoring. Endang Species Res 19:75-83

Knight MA, Vainickis AA (2011) Interactions with Threatened, Endangered or Protected Species in South Australian managed fisheries - 2007/08, 2008/09, and 2009/10. Report to PIRSA Fisheries and Aquaculture. SARDI Publ No. F2009/000544-1. SARDI Res Rep Ser. South Australian Research and Development Institute (Aquatic Sciences), Adelaide

Kusch A, Marin M (2012) On the distribution of the king penguin Aptenodytes patagonicus (Aves: Spheniscidae) in Chile. An Inst Patagonia 40:157-163

Larcombe J, Noriega R, Timmiss T (2016) Catch reporting under E-monitoring in the Australian Pacific longline fishery. CC BY 3.0. Australian Bureau of Agricultural and Resource Economics and Sciences (ABARES), Canberra. https://www.wcpfc.int/system/files/WCPFC-2016-ERand EMWG2-DP01 \%20Australian\%20ETBF\%20e-monitoring. pdf

ㄴ.Ludynia K, Kemper J, Roux JP (2012) The Namibian Islands' Marine Protected Area: using seabird tracking data to define boundaries and assess their adequacy. Biol Conserv 156:136-145

Luna-Jorquera G, Culik BM (1999) Diving behaviour of Humboldt penguins Spheniscus humboldti in northern Chile. Mar Ornithol 27:67-76

Lyle JM, Bell JD, Chuwen BM, Barrett N, Tracey SR, Buxton CD (2014) Assessing the impacts of gillnetting in Tasmania: implications for by-catch and biodiversity. Institute for Marine and Antarctic Studies, University of Tasmania, Hobart

MAE-DPNG (Ministerio del Ambiente del Ecuador-Dirección Parque Nacional Galápagos) (2006) Plan de Manejo. Parque Nacional Galápagos, Quito 
Majluf P, Babcock EA, Riveros JC, Schreiber MA, Alderete W (2002) Catch and bycatch of sea birds and marine mammals in the small-scale fishery of Punta San Juan, Peru. Conserv Biol 16:1333-1343

Marinao C, Yorio P (2011) Use of fishery discards and incidental mortality of seabirds attending coastal shrimp trawlers in Isla Escondida, Patagonia, Argentina. Wilson J Ornithol 123:709-719

Marinao C, Góngora ME, González-Zevallos D, Yorio P (2014) Factors affecting Magellanic penguin mortality at coastal trawlers in Patagonia, Argentina. Ocean Coast Manag 93:100-105

Martin GR, Crawford R (2015) Reducing bycatch in gillnets: a sensory ecology perspective. Glob Ecol Conserv 3: 28-50

Mattern T (2001) Foraging strategies and breeding success in the little penguin, Eudyptula minor: a comparative study between different habitats. MSc thesis, University of Otago, Dunedin

Mattern T (2013a) Fiordland penguin, Eudyptes pachyrhynchus. In: García-Borboroglu P, Boersma PD (eds) Penguins: natural history and conservation. University of Washington Press, Seattle, WA, p 152-167

Mattern T (2013b) Snares penguin, Eudyptes robustus. In: García-Borboroglu, Boersma PD (eds) Penguins: natural history and conservation. University of Washington Press, Seattle, WA, p 168-183

Mattern T, Ellenberg U, Houston DM, Davis LS (2007) Consistent foraging routes and benthic foraging behaviour in yellow-eyed penguins. Mar Ecol Prog Ser 343:295-306

Mattern T, Houston DM, Lalas C, Setiawan AN, Davis LS (2009) Diet composition, continuity in prey availability and marine habitat - keystones to population stability in the Snares penguin (Eudyptes robustus). Emu 109:204-213

Mattern T, Ellenberg U, Houston DM, Lamare M, Davis LS, van Heezik Y, Seddon PJ (2013) Straight line foraging in yellow-eyed penguins: new insights into cascading fisheries effects and orientation capabilities of marine predators. PLOS ONE 8:e84381

Mattern T, Meyer S, Ellenberg U, Houston D and others (2017) Quantifying climate change impacts emphasises the importance of managing regional threats in the endangered yellow-eyed penguin. PeerJ 5:e3272

McCutcheon C, Dann P, Salton M, Renwick L, Gormley A, Arnould J (2011) Foraging range of little penguins during winter. Emu 111:321-329

McKinlay B (1997) The conservation of yellow-eyed penguins Megadyptes antipodes: use of a PVA model to guide policy developments for future conservation management direction. Wildlife Management Report. University of Otago, Dunedin

Melvin EF, Parrish JK, Conquest LL (1999) Novel tools to reduce seabird bycatch in coastal gillnet fisheries. Conserv Biol 13:1386-1397

Ministry of Primary Industries (2012a) Official Information Act 1982, request OIA12-357, June 2012. Ministry of Primary Industries, Wellington

Ministry of Primary Industries (2012b) Set netting in a defined area on the east coast of the South Island. Ministry of Primary Industries, Wellington

Ministry of Primary Industries (2015) National Aquatic Biodiversity Information System (NABIS) - Internet mapping of New Zealand's marine environment, species distribution and fisheries management. Ministry of Primary Industries, Wellington
Ministry of Primary Industries (2017) Official Information Act 1982, request OIA17-0407, June 2012. Ministry of Justice, Wellington

Moore PJ, Wakelin M, Douglas ME, McKinlay B, Nelson D, Murphy B (1995) Yellow-eyed penguin foraging study, south-eastern New Zealand 1991-1993. Sci Res Ser No. 83. Department of Conservation, Wellington

Moreno CA, Rubilar PS, Marschoff E, Benzaquen L (1996) Factors affecting the incidental mortality of seabirds in the Dissostichus eleginoides fishery in the Southwest Atlantic (Subarea 48.3, 1995 season). CCAMLR Sci 3: 79-91

Moreno CA, Arata JA, Rubilar P, Hucke-Gaete R, Robertson G (2006) Artisanal longline fisheries in southern Chile: lessons to be learned to avoid incidental seabird mortality. Biol Conserv 127:27-36

Nel DC, Ryan PG, Watkins BP (2002) Seabird mortality in the Patagonian toothfish longline fishery around the Prince Edward Islands. Antarct Sci 14:151-161

Nisbet ICT, Dann P (2009) Reproductive performance of little penguins in relation to year, age, pair-bond duration, breeding date and individual quality. J Avian Biol 40: 296-308

Norman FI (2000) Preliminary investigation of the bycatch of marine birds and mammals in inshore commercial fisheries, Victoria, Australia. Biol Conserv 92:217-226

* Numata M, Davis LS, Renner M (2000) Prolonged foraging trips and egg desertion in little penguins (Eudyptula minor). N Z J Zool 27:277-289

O'Doherty F (2014) Death of 25 fairy penguins found at Altona Beach renews calls for commercial fishing net ban in Port Phillip Bay. Hobsons Bay Leader (10 September 2014), Preston

* Oliveira N, Henriques A, Miodonski J, Pereira J and others (2015) Seabird bycatch in Portuguese mainland coastal fisheries: an assessment through on-board observations and fishermen interviews. Glob Ecol Conserv 3:51-61

Ortiz N, Mangel JC, Wang J, Alfaro-Shigueto J and others (2016) Reducing green turtle bycatch in small-scale fisheries using illuminated gillnets: the cost of saving a sea turtle. Mar Ecol Prog Ser 545:251-259

* Pelletier L, Chiaradia A, Kato A, Ropert-Coudert Y (2014) Fine-scale spatial age segregation in the limited foraging area of an inshore seabird species, the little penguin. Oecologia 176:399-408

Pierre JP, Cleal J, Thompson FN, Abraham ER (2013) Seabird bycatch reduction in scampi trawl fisheries. Final Research Report for Department of Conservation project MIT2011-02. Department of Conservation, Wellington

*Pozzi LM, García-Borboroglu P, Boersma PD, Pascual MA (2015) Population regulation in Magellanic penguins: What determines changes in colony size? PLOS ONE 10: e0119002

Prochazka K (2014) Status of the South African marine fishery resources 2014. Department of Agriculture, Forestry and Fisheries, Pretoria

* Pütz K, Hiriart-Bertrand L, Simeone A, Riquelme V, ReyesArriagada R, Lüthi B (2011) Entanglement and drowning of a Magellanic penguin (Spheniscus magellanicus) in a gill net recorded by a time-depth recorder in southern Chile. Waterbirds 34:121-125

Ramm K (2010) Conservation Services Programme observer report: 1 July 2008 to 30 June 2009. Department of Conservation, Wellington 
Ramm K (2012a) Conservation Services Programme observer report: 1 July 2009 to 30 June 2010. Department of Conservation, Wellington

Ramm K (2012b) Conservation Services Programme observer report: 1 July 2010 to 30 June 2011. Department of Conservation, Wellington

Richard Y, Abraham ER (2013) Risk of commercial fisheries to New Zealand seabird populations. Ministry of Primary Industries, Wellington

Richard Y, Abraham ER (2015) Assessment of the risk of commercial fisheries to New Zealand seabirds, 2006-07 to 2012-13. New Zealand Aquatic Environment and Biodiversity Report 162. Ministry of Primary Industries, Wellington

Robson B, Glass T, Glass N, Glass J (2011) Revised population estimate and trends for the Endangered northern rockhopper penguin Eudyptes moseleyi at Tristan da Cunha. Bird Conserv Int 21:454-459

Ropert-Coudert Y, Chiaradia A, Kato A (2006) An exceptionally deep dive by a little penguin Eudyptula minor. Mar Ornithol 34:71-74

Ropert-Coudert Y, Kato A, Chiaradia A (2009) Impact of small-scale environmental perturbations on local marine food resources: a case study of a predator, the little penguin. Proc R Soc B 276:4105-4109

Roux MJ, Brewin P, Jurgens E, Winter A (2012) Scientific report, fisheries cruise ZDLT1-08-2012. Fisheries Department, Directorate of Natural Resources, Falkland Islands Government, Stanley

Roux JP, van der Lingen CD, Gibbons MJ, Moroff NE, Shannon LJ, Smith ADM, Cury PM (2013) Jellyfication of marine ecosystems as a likely consequence of overfishing small pelagic fishes: lessons from the Benguela. Bull Mar Sci 89:249-284

Rowe S (2008) Monitoring penguin bycatch in commercial setnet fisheries. N Z J Zool 35:299

Rowe SJ (2009) Conservation Services Programme observer report: 01 July 2004 to 30 June 2007. DOC Marine Conservation Services Series 1. Department of Conservation, Wellington

Rowe S (2010) Level 1 risk assessment for incidental seabird mortality associated with New Zealand fisheries in the NZ-EEZ. Marine Conservation Services, Department of Conservation, Wellington. www.doc.govt.nz/mcs

Ryan PG, Cooper J (1991) Rockhopper penguins and other marine life threatened by driftnet fisheries at Tristan da Cunha. Oryx 25:76-79

Schiavini A, Yorio P, Gandini P, Raya-Rey A, Boersma D (2005) Los pingüinos de las costas argentinas: estado poblacional y conservación. Hornero 20:5-23

Schlatter RP, Paredes E, Ulloa J, Harris J and others (2009) Mortandad de pingüino de Magallanes (Spheniscus magellanicus) en Queule, Región de la Araucanía, Chile. Bol Chil Ornitol 15:78-86

Seco Pon JP, Copello S, Moretinni A, Lertora HP and others (2013) Seabird and marine-mammal attendance and bycatch in semi-industrial trawl fisheries in near-shore waters of northern Argentina. Mar Freshw Res 64: 237-248

Seddon PJ, Ellenberg U, van Heezik Y (2013) Yellow-eyed penguin (Megadyptes antipodes). In: García-Borboroglu P, Boersma PD (eds) Penguins: natural history and conservation. University of Washington Press, Seattle WA, p 91-110

Setiawan A, Massaro M, Darby J, Davis L (2005) Mate and territory retention in yellow-eyed penguins. Condor 107 : 703-709

Shelton PA, Crawford RJM, Cooper J, Brooke RK (1984) Distribution, population size and conservation of the jackass penguin Spheniscus demersus. S Afr J Mar Sci 2:217-257

Sherley RB, Ludynia K, Dyer BM, Lamont T and others (2017) Metapopulation tracking juvenile penguins reveals an ecosystem-wide ecological trap. Curr Biol 27: 563-568

Simeone A, Bernal M, Meza J (1999) Incidental mortality of Humboldt penguins Spheniscus humboldti in gill nets, central Chile. Mar Ornithol 27:157-161

Skewgar E, Simeone A, Boersma PD (2009) Marine reserve in Chile would benefit penguins and ecotourism. Ocean Coast Manag 52:487-491

Stevenson C, Woehler EJ (2007) Population decreases in little penguins Eudyptula minor in southeastern Tasmania, Australia, over the past 45 years. Mar Ornithol 35:71-76

Stokes DL, Boersma PD, Casenave JL, García-Borboroglu P (2014) Conservation of migratory Magellanic penguins requires marine zoning. Biol Conserv 170:151-161

* Suazo CG, Schlatter RP, Arriagada AM, Cabezas LA, Ojeda J (2013) Fishermen's perceptions of interactions between seabirds and artisanal fisheries in the Chonos archipelago, Chilean Patagonia. Oryx 47:184-189

Suazo CG, Cabezas LA, Moreno CA, Arata JA and others (2014) Seabird bycatch in Chile: a synthesis of its impacts, and a review of strategies to contribute to the reduction of a global phenomenon. Pac Seabirds 41:1-12

Suazo CG, Cabezas LA, Yates O (2016) Collaboration on technical innovation towards the reduction of seabird bycatch in purse seine fisheries. 7th Meeting of the Seabird Bycatch Working Group, Agreement on the Conservation of Albatrosses and Petrels, La Serena, Chile

Sullivan BJ, Reid TA, Bugoni L (2006) Seabird mortality on factory trawlers in the Falkland Islands and beyond. Biol Conserv 131:495-504

* TAAF (Terres Australes et Antarctiques Françaises) (2011) Taking action for the Amsterdam albatross. A synopsis of the national plan of actions 2011-2015. www.taaf.fr/ IMG/pdf/brochure_pna-eng_web.pdf

Tamini LL, Perez JE, Chiaramonte GE, Cappozzo HL (2002) Magellanic penguin Spheniscus magellanicus and fish as bycatch in the cornalito Sorgentinia incisa fishery at Puerto Quequen, Argentina. Atl Seabirds 4:109-114

Trathan PN, García-Borboroglu P, Boersma D, Bost CA and others (2015) Pollution, habitat loss, fishing, and climate change as critical threats to penguins. Conserv Biol 29: 31-41

UNIVALI (Universidade do Vale do Itajaí) (2009) Boletim estatístico da pesca industrial de Santa Catarina - ano 2008: programa de apoio técnico e científico ao desenvolvimento da pesca no Sudeste e Sul do Brasil, Itajaí. Centro de Ciências Tecnológicas da Terra e do Mar, Universidade do Vale do Itajaí, Itajaí

Vasconcellos M, Haimovici M, Ramos K (2014) Pesca de emalhe demersal no sul do Brasil: evolução, conflitos e (des) ordenamento. In: Haimovici M, Andriguetto-Filho JM, Sunye PS (eds) A pesca marinha e estuarina no Brasil: estudos de caso multidisciplinares. Editora da FURG, Rio Grande, p 29-40

Walker BG, Boersma PD (2003) Diving behaviour of Magellanic penguin (Spheniscus magellanicus) at Punta Tombo, Argentina. Can J Zool 81:1471-1483

Wallace BP, Lewison RL, McDonald SL, McDonald RK and 
others (2010) Global patterns of marine turtle bycatch. Conserv Lett 3:131-142

Wang J, Barkan J, Fisler S, Godinez-Reyes C, Swimmer Y (2013) Developing ultraviolet illumination of gillnets as a method to reduce sea turtle bycatch. Biol Lett 9:20130383

Watkins BP, Petersen SL, Ryan PG (2008) Interactions between seabirds and deep-water hake trawl gear: an assessment of impacts in South African waters. Anim Conserv 11: 247-254

Weimerskirch H, Capdeville D, Duhamel G (2000) Factors affecting the number and mortality of seabirds attending trawlers and long-liners in the Kerguelen area. Polar Biol 23:236-249

Wilson RP, Wilson MPT, Duffy DC (1988) Contemporary and historical patterns of African penguins Spheniscus

Editorial responsibility: Brendan Godley,

University of Exeter, Cornwall Campus, UK demersus: distribution at sea. Estuar Coast Shelf Sci 26: 447-458

KYorio P, Caille G (1999) Seabird interactions with coastal fisheries in northern Patagonia: use of discards and incidental captures in nets. Waterbirds 22:207-216

* Yorio P, Quintana F, Dell'Arciprete P, González-Zevallos D (2010) Spatial overlap between foraging seabirds and trawl fisheries: implications for the effectiveness of a marine protected area at Golfo San Jorge, Argentina. Bird Conserv Int 20:320-334

Zavalaga C, Paredes R (1997) Humboldt penguins at Punta San Juan, Peru. Penguin Conserv 10:6-8

Žydelis R, Small C, French G (2013) The incidental catch of seabirds in gillnet fisheries: a global review. Biol Conserv 162:76-88

Submitted: February 21, 2017; Accepted: October 7, 2017

Proofs received from author(s): November 22, 2017 